\title{
DOES COMPETITION AMONG \\ PUBLIC SCHOOLS BENEFIT \\ STUDENTS AND TAXPAYERS?
}

Caroline Minter Hoxby

Working Paper No. 4979

\section{NATIONAL BUREAU OF ECONOMIC RESEARCH \\ 1050 Massachusetts Avenue \\ Cambridge, MA 02138 \\ December 1994}

I am grateful to Henry Farber, James Poterba, Jonathan Gruber, Franklin Fisher, Steve Pischke, Kevin Lang, Larry Katz, and seminar participants at Harvard and M.I.T. for many helpful comments. I gratefully acknowledge funding from a Ford Foundation Dissertation Fellowship and a Spencer Foundation Fellowship for Research Related to Education. All errors are my own. This paper is part of NBER's research program in Public Economics. Any opinions expressed are those of the author and not those of the National Bureau of Economic Research.

(C) 1994 by Caroline Minter Hoxby. All rights reserved. Short sections of text, not to exceed two paragraphs, may be quoted without explicit permission provided that full credit, including $\odot$ notice, is given to the source. 
NBER Working Paper \#4979

December 1994

\title{
DOES COMPETITION AMONG \\ PUBLIC SCHOOLS BENEFIT \\ STUDENTS AND TAXPAYERS?
}

\begin{abstract}
Many school choice proposals would enable parents to choose among public school districts in their area, though not among private schools. Theory predicts three reactions to easier choice among public schools. The first is increased sorting of students and parents among schools. Analysts instinctively worry that, with greater sorting, advantaged students will gain at the expense of disadvantaged students. The second predicted reaction is that easier choice will encourage competition among schools, forcing them into higher productivity (better student performance per input). The third and final prediction is that easier choice among public schools will give parents less incentive to send their children to private schools. There is very little empirical evidence to substantiate any of these predictions, and this study attempts to fill that gap. I examine easing choice among public schools using exogenous variation in the concentration of public school districts in metropolitan areas measured by a Herfindahl index on enrollment shares. The exogenous variation is generated by topography: I derive instruments for concentration from natural boundaries (rivers) that partially determine district size. I find strong evidence that easier choice leads to greater productivity. Areas with greater opportunities for choice among public schools have lower per-pupil spending, lower teacher salaries, and larger class sizes. The same areas have better average student performance, as measured by students' educational attainment, wages, and test scores. I find evidence of increased sorting but no evidence that disadvantaged groups are harmed by the sorting. Improvements in student performance are concentrated among white non-Hispanics, males, and students who have a parent with at least a high school degree. However, student performance is not worse among Hispanics, African-Americans, females, or students who do not have a parent with a high school degree. Also, student performance improves at both ends of the educational attainment distribution and test score distribution. Finally, I find strong evidence that a smaller share of students attend private schools in areas where choice among public schools is easier.
\end{abstract}

Caroline Minter Hoxby

Department of Economics

Harvard University

Cambridge, MA 02138

and NBER 


\section{Introduction}

Many school choice plans being debated propose to ease parental choice among public school districts. Theory predicts at least three reactions to easier choice among public schools, and these reactions, though not mutually exclusive, tend to support opposite sides of the school choice debate. The first predicted reaction is increased sorting of students and parents among schools. The effect of such sorting on students cannot be predicted: there is no convincing empirical evidence that increased sorting leads to greater inequality of school inputs, there is little theoretical or empirical basis for notions that students perform better or worse when placed with more homogeneous peers, there is considerable debate about whether greater school inputs improve student performance. Nevertheless, analysts instinctively worry that, with greater sorting, advantaged students will gain at the expense of disadvantaged students. The second predicted reaction is that easier choice will encourage competition among schools, forcing them into higher productivity (better student performance per input). The third and final prediction is that easier choice among public schools will give parents less incentive to send their children to private schools. This study provides rigorous empirical tests of these predictions using exogenous variation in the concentration of public school districts in metropolitan areas.

The empirical strategy of this study is to find sources of long-term differences in ease of choice among public schools that are exogenous to school conduct and performance. These differences must be long-term because we expect the public school equilibrium to adjust slowly to changes in the ease of choice. Parents are slow to move their children between public school districts owing to fixed financial costs and psychic costs to children, whose school performance may deteriorate as a result. Public schools adjust their conduct slowly because their institutional structure and, typically, their union contracts 
hamper rapid change in enrollment, staff, or curriculum.

This study takes the view that long-term differences in the ease of choice among school districts are generated by differences in the concentration of school districts in a metropolitan area. The ability to choose among districts will be a function both of the number of districts in the metropolitan area and the evenness with which enrollment is spread over those districts. Thus, choice is easier in a metropolitan area where parents choose among twenty districts of equal size than in an area where threequarters of enrollment falls into one of twenty districts than in an area with only one school district. A Herfindahl index based on enrollment shares summarizes these differences in concentration. ${ }^{1}$

School districting, and thus school district concentration, is largely a result of historical accident and topography, but is partly endogenous to unobserved factors that also influence school conduct and performance. Consider two scenarios under which school district consolidations, which are almost always voluntary, often occur. The first is when a metropolitan area experiences thinning population and falling incomes, typically resulting from losses in an important industry. In this scenario, districts find themselves with rising fixed costs per pupil at the same time as they are under pressure to reduce perpupil spending in line with falling incomes. Two or more districts will consolidate in order to save on fixed costs. Areas with consolidations of this type have an unobserved trajectory of decline that may account for low school inputs per pupil or low student performance that is apparently idiosyncratic. The second scenario is when a metropolitan area is growing and absorbing once rural jurisdictions. In this case, rural districts that once had low population density and could offer only a basic curriculum are absorbed into suburban districts that offer a complex menu of courses, vocational training, and activities. Areas with consolidations of this type have an unobserved trajectory of growth that may account for large school inputs per pupil or good student performance that is apparently idiosyncratic. Thus, the part of school district concentration that is endogenous to unobserved factors that influence schools may lead to

\footnotetext{
1 Calculate for every school district in a metropolitan area its share of total metropolitan area enrollment. The Herfindahl index is the sum of squared enrollment shares. It falls on the $[0,1]$ interval and is decreasing in the number of districts and the evenness of enrollment shares.
} 
either negative or positive bias in our estimates of the effect of concentration on school conduct and performance.

This study uses exogenous determinants of school districting, natural boundaries (rivers), as instrumental variables for potentially endogenous concentration. I thus identify the effects of long-term, exogenous differences in ease of choice among public schools.

The Herfindahl index of enrollment concentration in a metropolitan area is the independent variable of interest. We need to examine outcomes which describe both school conduct and student performance. To describe school conduct, I examine per-pupil spending, teacher salaries, and studentteacher ratios for public schools in each metropolitan area $\left(\mathrm{SMSA}^{2}\right)$ of the U.S. These variables are drawn from the Census of Governments. I measure students' performance by educational attainment, wages, and Armed Forces Qualifications Test scores. These data are drawn from the National Longitudinal Survey of Youth.

The organization of the remainder of this paper is as follow. Section II explains the three predicted responses to easier school choice, the models for which are found in cited, related literature. The section also specifies equations to be estimated. Section III contains a simple model of the determinants of enrollment concentration, and describes the data more fully. Section IV contains results for the effects of enrollment concentration on per-pupil spending, teacher salaries, and class size. Results for the effects of concentration on student performance are discussed in section V. Section VI presents results that test whether private schooling is less prevalent in areas with low concentration. Finally, Section VII draws brief conclusions, including a comparison of competition among public schools to competition between public and private schools.

2 Standard Metropolitan Statistical Areas, as defined in 1980. For New England states, the New England County Metropolitan Area (NECMA) is used in preference to the SMSA. 
II. Sorting, Changes in Productivity, and Greater Private School Enrollment as Reponses to Easier

\section{Choice}

The Prediction that Sorting Increases

The intuition for the prediction that easier choice among schools districts generates greater sorting of students among districts is straightforward. Suppose that no private schools exist and that public school districts are characterized only by the rental price of housing and school quality. Households differ in their incomes and taste for school quality. In a metropolitan area with one school district, households of all incomes and tastes send their children to the one school system and no sorting takes place. In an area with many districts, households choose a district to maximize their utility over school quality and other consumption (which includes consumption of housing) under a budget constraint given by income. The result is sorting along lines of both income and taste for school quality, so that the expectation of income or taste conditional upon living in a given school district is not equal to the unconditional expectation.

Increased sorting of students is clearly predicted when choice is made easier. The effect of such sorting on student performance is ambiguous. Epple and Romano (1993) and Benabou (1993a, 1993b) develop more elaborate models of sorting among school districts in order to reach the prediction that sorting has a negative effect on student performance. ${ }^{3}$ Obviously, such extensions require assumptions about the form of the education production function: not only restrictions on the relationship of school inputs to student performance but also on whether students perform better when schooled with homogeneous or heterogenous peers. This study remains agnostic about the predicted effect of sorting, merely looking for evidence of sorting and for evidence that sorting has negative effects on at least some

\footnotetext{
${ }^{3}$ Note also the contributions of Epple, Filimon, and Romer $(1983,1984)$ and Epple and Zelnitz (1981).
} 
students. ${ }^{4}$ Such evidence would be, in metropolitan areas with exogenously lower concentration, increased disparity in school inputs per student or worse performance of those students most expected to lose through sorting--African-Americans, Hispanics, students whose parents have lower education or income. Examples of estimating equations I use are:"

$$
\left(\mathrm{hgc}_{\mathrm{ij}} \mid \mathrm{i} \text { belongs to race } \mathrm{k}\right)=\beta_{\mathrm{k}} \mathrm{H}_{\mathrm{j}}+\mathrm{W}_{\mathrm{j}} \alpha_{\mathrm{ik}}+\mathrm{W}_{\mathrm{ij}} \alpha_{2 \mathrm{k}}+\epsilon_{\mathrm{j}}+\epsilon_{\mathrm{ij}}
$$

where: $\quad \mathrm{i}$ indexes individuals

$$
\begin{aligned}
& \mathrm{j} \text { indexes SMSAs } \\
& \text { hgc }_{\mathrm{ij}}=\text { highest grade completed by individual } \mathrm{i} \text { in SMSA } \mathrm{j} \\
& \mathrm{H}_{\mathrm{j}}=\text { Herfindahl index of enrollment concentration in SMSA } \mathrm{j} \\
& \mathrm{W}_{\mathrm{j}}=\text { vector of SMSA characteristics } \\
& \mathrm{W}_{\mathrm{ij}}=\text { vector of individual background variables } \\
& \epsilon_{\mathrm{j}}=\text { unexplained SMSA effect } \\
& \epsilon_{\mathrm{ij}}=\text { unexplained individual effect }
\end{aligned}
$$

$$
\text { std.dev(per pupil spending })=\delta \mathrm{H}_{\mathrm{j}}+\mathrm{W}_{\mathrm{j}} \gamma+\xi_{\mathrm{j}}
$$

where: $\quad$ std.dev(per pupil spending, $=$ standard deviation of per pupil spending among school districts in SMSA j

$$
\begin{aligned}
& W_{j}=\text { vector of SMSA characteristics } \\
& \xi_{j}=\text { unexplained SMSA effect }
\end{aligned}
$$

\section{The Prediction that Productivity Increases}

The prediction that easier choice leads to increased school productivity is a branch of the local

4 Empirically, it would be difficult and not very productive to determine whether improvements in student performance resulted from potentially positive effects of sorting or from greater school productivity. Homogeneity of students undoubtedly influences the use of many school inputs.

5 See Appendix Table 1 for list of variables in $\mathrm{W}_{\mathrm{ij}}$ and $\mathrm{W}_{\mathrm{j}}$, variable definitions, and descriptive statistics. 
public goods provision literature deseminating from Tiebout (1956). Tiebout and most of the related literature simply assume that local governments provide public goods at minimum average cost because they are concerned with the problem of whether local governments provide the optimal amount of public goods. A particular, and perhaps most realistic, version of the Tiebout hypothesis supposes that the value of local public goods are fully capitalized in property values within a jurisdiction. Then, as the fixed cost of creating a jurisdiction falls, the ho'sseholds that select into any jurisdiction are increasingly homogeneous in their demands for local public goods, and local governments provide public goods that more closely approximate individual households' optimal choices. ${ }^{\circ}$

One branch of the Tiebout literature alters the question to ask whether local governments have higher productivity in their production of public goods as the fixed cost of creating a jurisdiction falls. The argument is that the capitalized value of local public goods falls from the monopoly price to the competitive price as the fixed cost of creating a jurisdiction falls. The decrease in monopoly "profits" is manifested in an increase in local government productivity. Articles such as Eberts and Gronberg (1981), Pack and Pack (1978), and Borland and Howsen (1992) take the view that a metropolitan area with many jurisdictions effectively has lower fixed costs of creating a jurisdiction to respond to public goods demands of a group of households. Such articles typically find that the greater the number or lower the concentration of jurisdictions, the greater the productivity of local governments. None of these articles, however, deals with the problem that jurisdictional concentration is potentially endogenous.

This study looks for evidence that the productivity of public schools is higher when the concentration of school districts is exogenously lower. Such evidence would be better student performance for a given level of inputs. Note that, because economies or diseconomies of scale might also affect school productivity, it is necessary to control for the absolute enrollment of schools in a

\footnotetext{
6 See Tiebout (1956) and. If property taxes are the means of financing local government, full efficiency is not achieved.
} 
metropolitan area. Examples of estimating equations I use are:

$$
h_{g c}=\theta H_{j}+W_{j} k_{1}+W_{i j} k_{2}+v_{j}+v_{i j}
$$

where all variables are defined above except:

$$
\begin{aligned}
& v_{\mathrm{j}}=\text { unexplained SMSA effect } \\
& v_{\mathrm{ij}}=\text { unexplained individual effect }
\end{aligned}
$$

$$
\text { per pupil spending }=\lambda H_{j}+W_{j} \mu+\iota_{j}
$$

where all variables are defined above except:

$$
\iota_{j}=\text { unexplained SMSA effect }
$$

\section{The Prediction that Private Schools Enroll a Smaller Share of Students}

The prediction that easier choice among public schools decreases the share of metropolitan area enrollment going to private schools is a simple extension of the sorting prediction. Where households are able sort themselves more fully among public schools districts, they attain higher utility in the public sector and are less likely to gain enough additional utility from sending children to private schools to cover the loss of utility associated with paying private tuition. Thus, this study attempts to find evidence for the prediction that, in metropolitan areas with exogenously lower concentration, a smaller share of students attend private schools. An estimating equation I use is:

$$
\text { private share of enrollment }{ }_{j}=\pi H_{j}+W_{j} \rho+\omega_{j}
$$

where all variables are defined above except:

$$
\begin{aligned}
& \text { private share of enrollment } t_{j}=\text { share of SMSA j's enrollment in private schools } \\
& \omega_{j}=\text { unexplained SMSA effect }
\end{aligned}
$$

\section{The Determinants of Enrollment Concentration and the Data \\ The Determinants of Enrollment Concentration}


Current school districting is determined by initial schooling districting, which generally took place during the period of Anglo-American settlement of the state, and changes in districting since that time, which are endogenous to school conduct and performance. Initial district lines were typically drawn to maximize some objective function which had, as arguments, school size (the the contemporary education production function determined optimal size: below some enrollment, underuse of fixed inputs made schooling inefficient; above some enrollment, schooling became unwieldy and there were diseconomies of scale) and time and cost of travel to school. Consider a metropolitan area, as defined in 1980. Suppose, for simplicity, that enrollment concentration is a sufficient statistic for all relevant aspects of school districting that affect school size and distance to school. At initial settlement, the problem is

$$
\max _{H 0} V\left(H_{0}\right)=v\left(H_{0}\right)-c\left(H_{0}, R, X_{0}\right)
$$

where: $\quad$ " 0 " subscripts indicate value of variable at time of settlement, variables with no subscript are time-invariant

$v\left(H_{0}\right)=$ value-added per student $=$ value of human capital acquired by student - cost to taxpayer of providing schoolng

$c\left(H_{0}, R, X_{0}\right)=$ cost, in utility, of travel to school for the average student, including opportunity cost of time spend travelling ${ }^{7}$

$H_{0}=$ Herfindahl index of enrollment concentration

$\mathbf{R}=$ vector of natural, topographical boundaries like rivers that increase the time and cost of travelling to school for a given distance to school

$X_{0}=a$ vector of variables that affect relationship between enrollment concentration and distance to school, including population density, area (in square miles), transportation technology at time of settlement

7 For example, in 18th century petitions for school district boundaries (usually coincident with parish boundaries), a very common argument was the distance a person could reasonably be expected to walk to a parish church or school. 
The solution to the problem gives a reduced form for intial enrollment concentration:

$$
H_{0}=f\left(R, X_{0}\right)
$$

Current enrollment concentration is a function of initial enrollment concentration $\left(\mathrm{H}_{0}\right)$, current values of $\mathbf{X}$, and $\mathbf{Z}$

$$
H_{t}=g\left(H_{0}, X, Z\right)=h\left(R, X_{0}, X, Z\right)
$$

where:

$\mathrm{Z}=$ indicators of past and current school conduct and performance that affect current enrollment concentration, including changes in the education production function, idiosycratic inputs to or tastes for education

A linearized version of equation 8 is the "first stage" of instrumental variables estimation of equations 1-5 (and their variants) which test the predicted responses to easier choice:

$$
H_{j}=R_{j} \psi_{1}+X_{j} \psi_{2}+Z_{j} \psi_{3}+\zeta_{j}
$$

where: $\quad \varsigma_{\mathrm{j}}=$ unexplained SMSA effect

The identifying restrictions are based on using the vector of river variables, $R$, as the identifying instrumental variables:

$$
\operatorname{plim}(1 / \mathrm{n}) \mathrm{R}^{\prime} \mathrm{e}=0 \text { and } \operatorname{plim}(1 / \mathrm{n}) \mathrm{R}^{\prime} \mathrm{H} \neq 0
$$

where: $\quad$ e stands for the unexplained component of the relevant equation (from equations 1-5 and their variants)

$n=$ number of observations over which the relevant equation (from equations $1-5$ and their variants) is estimated

To avoid imposing any additional identifying restrictions, I let

$$
\left[X_{j} Z_{j}\right]=W_{j}
$$


The data used in this study come from several sources, which are matched geographically and center on the year 1980. Data on public school districts and local governments come from the 1982 Census of Governments. The Census includes 16,270 school districts (which control more than 85,000 schools). This is the source of information on public school enrollment, spending, sources of revenue, teacher employment, teacher salaries, and student-teacher ratio.

Private school data are taken from the National Center for Education Statistics (NCES) Private Schools in American survey, 1980 . This survey of 20,050 schools accounts for $95 \%$ of the private schools in the U.S. Since missing schools tend to be small, the survey accounts for an even larger percentage of private enrollment. The key variables from this source are enrollment, grade levels taught, and SMSA.

Student data come from the National Longitudinal Survey of Youth (NLSY), a panel of 12,686 young men and women surveyed every year since 1979. The men and women were ages 14-22 in 1979, so that respondents can be followed from secondary school, through post-secondary education, and into the job market of their mid-twenties through early-thirties. In an effort to associate individuals with the SMSA in which they attended school, each respondent was matched with the SMSA in which he or she lived at age 14. Variables drawn from the NLSY include the respondent's race, Hispanic origin, sex, number of siblings, and birth order; the educational attainment of his or her parents; and the religion in which he or she was raised.

Topographical data come from the U.S. Department of the Interior Geological Survey quadrangle maps. Bodies of water are by far the most common natural school district boundary in the U.S. In fact, boundaries composed of neither relatively straight lines nor bodies of water are somewhat rare. I recorded rivers, streams, creeks, inlets and similar bodies of water whose width exceeds 75 feet at some point and that extend at least five miles. They are classified either as inter-county "rivers" (where they form county boundaries) or as intra-county "rivers" (where a stretch of water flows inside a county's 
boundaries). $^{8}$ I divide rivers into these two classes because inter-county rivers tend to be more formidable natural boundaries and because school districts that cross county lines are extremely rare. Thus, rivers that form natural county boundaries are much more likely to remain permanent school district boundaries (in defiance of school consolidation movements) than intra-county rivers. The quadrangle map data were checked for accuracy against the Geological Survey's Geographic Names Information System (GNIS). ${ }^{9}$

Variables on adherence to religious denominations by SMSA were drawn from the Survey of Churches and Church Membership in the United States, 1980. This is a survey of 231,708 JudaeoChristian congregations, including 469 denominations and accounting for 112.5 million adherents. A person is counted as an adherent if he or she regularly attends religious services associated with a congregation.

Finally, the 1980 Census of Population and the 1983 City and County Data Book are the sources for numerous SMSA characteristics used to help explain the demand for and quality of public and private schools. The most important variables describe the distribution of income (per capita income, share of households below the poverty level, Gini coefficient, etcetera) and education (share of adults with 12 years of education, with 16 years of education). In addition, variables are used that describe urbanness, racial composition, (social welfare) program participation, and region.

Appendix Table 1 contains descriptive statistics for both SMSA-level variables $\left(W_{j}\right)$ and individual-level variables $\left(\mathrm{W}_{\mathrm{ij}}\right)$ used in this study. Appendix Table 2 shows SMSA characteristics by quartile of the SMSA's number of rivers--that is, whether the SMSA has a large or small number of

B Hereafter all recorded bodies of water are called "rivers" for simplicity.

9 For each U.S. county in an SMSA, I extracted the names of all topographical features in the relevant classifications (e.g. "stream") from the GNIS computer files. I also extracted each feature's location in the Geological Survey's quadrangle map system. Using the maps, features were measured and their positions relative to county boundaries were noted. 
rivers relative to other SMSAs. The table shows that SMSAs with different numbers of rivers do not appear to differ on observable characteristics that we expect to be determinants of school conduct and performance. Appendix Table 3 contains the Herfindahl index of enrollment concentration of SMSAs by U.S. state. The states with the lowest enrollment concentration are Connecticut, Maryland, Massachusetts, and Rhode Island; the SMSAs these states have Herfindahl indices that average .05 (equivalent to 20 school districts of equal enrollment in each SMSA). The states whose SMSAs have the highest enrollment concentration are Alaska, Hawaii, Nevada, and New Mexico; the SMSAs of these states have Herfindahl indices that exceed .90 on average (each SMSA has just one major public school district). Indices for SMSAs in other states of interest are: Arizona, .19; California, .10; Florida, .61; Illinois, .13; Louisiana, .57; Minnesota, .11; New York, .21; Pennsylvania, .08; Texas, .29.

Enrollment concentration has significant correlations with two observable characteristics of an SMSA: a negative correlation with land area in square miles and a negative correlation with total population. Also, enrollment concentration tends to be high in the Mountain and South Atlantic census regions and tends to be low in the New England and Pacific census regions.

Table 1 shows the results of estimating equation 9, the "first-stage" that predicts enrollment concentration with the vector of rivers variables and other SMSA characteristics. The four rivers variables explain a sizeable share of the variation in enrollment concentration. Each additional intracounty river lowers the Herfindahl index of enrollment concentration by .03 , and each additional intercounty river lowers the Herfindahl index of enrollment concentration by .05 . The partial F-statistic on the significance of the four river variables is $F_{4.260}=12.85^{10}$ which, taking consideration of the small number of observations, indicates that the identifying instruments are quite strongly correlated with concentration.

10 This partial F-statistic indicates that the instruments are not so weakly correlated with the potentially endogenous variable, enrollment concentration, that we need to be concerned about bias of the IV estimate towards the OLS estimate in small samples. See Staiger and Stock 1993. 
Appendix Table 4 shows the Herfindahl index of enrollment concentration and the share of enrollment in private schools for each SMSA in the U.S.

\section{Public School Enrollment Concentration and Public School Inputs}

This section tests the first half of the prediction that easier choice among public schools raises school productivity by examining the effect of exogenous concentration on per-pupil inputs, measured by per-pupil spending, teacher salaries, and student-teacher ratios. The equations, which are estimated by both ordinary least squares (OLS) and instrumental variables (IV), are:

$$
\begin{gathered}
\text { per pupil spending }=\lambda H_{j}+W_{j} \mu+\iota_{j} \\
\text { In(teacher salary) })_{j}=\lambda^{\prime} H_{j}+W_{j} \mu^{\prime}+\iota_{j}^{\prime} \\
\text { student-teacher ratio }{ }_{j}=\lambda^{\prime \prime} H_{j}+W_{j} \mu^{\prime \prime}+\iota^{\prime \prime} \text {. }
\end{gathered}
$$

This section also tests the prediction that easier choice among schools leads to sorting that may increase the disparity of per-pupil inputs among school districts. The equation, which is estimated by OLS and IV is:

$$
\text { std.dev(per pupil spending })=\delta H_{j}+W_{j} \gamma+\xi_{j} .
$$

Each equation contains 264 observations, one for each SMSA in the U.S. The IV estimates are identified by intra-county and inter-county rivers (and their squares). I report results of Hausman Lagrange Multiplier tests of overidentifying restrictions. These are partial tests of the validity of excluding the river variables from $W_{j}$.

Table 2 presents selected coefficients from estimating equation 4 by OLS and IV. The effect of enrollment concentration on per-pupil spending is substantial: a .4 increase in concentration (equivalent to a shift from 10 equal sized school districts to 2 equal sized school districts) generates an increase in per-pupil spending of \$203. (Mean per-pupil spending in U.S. SMSAs was \$2139 in 1982). The IV estimate implies that a .4 increase in concentration raises per-pupil spending by $\$ 219$. The statistic on 
the test of overidentifying restrictions, distributed asymptotically as chi-squared, is 3.70. At conventional levels of significance, we cannot reject the null hypothesis that the identifying restrictions are valid.

Certain other coefficients are worth noting. The state's share of public school spending is included as a regressor to allow for the fact that local school districts control different shares of their finances in different states. It does not appear to affect per-pupil spending as both its OLS and IV estimated coefficients are insignificantly ${ }^{11}$ different from zero. Per-pupil spending is increasing in the land area of the SMSA, increasing in per capita income, and decreasing in the share of households headed by females. Interestingly, per-pupil spending is increasing in the share of households below the poverty level. This effect may be due to the fact that state and federal spending on schools is often calibrated by the number of students from households below the poverty level.

Table 2a shows IV estimates of the coefficient on concentration based on equation 4 , for various subgroups of SMSAs. Sample sizes are necessarily small, but it appears that the result that per-pupil spending is increasing in exogenous concentration derives from SMSAs that are relatively compact and have above median population densities and African-American population shares.

Table 3 reports the results of estimating equation 4', which has the natural log of average teacher's salary as the dependent variable. The OLS estimate indicates that a .4 increase in the Herfindahl index of public school enrollment concentration raises teacher salaries by $2 \%$ on average. The IV estimate is substantially larger: it indicates that a .4 increase in the index raises teacher salaries by $7 \%$ on average.

The OLS and IV estimated coefficients on the share of school expenditure from state funds indicate that a .1 increase in the state's share generates a $1 \%$ decrease in the average teacher's salary.

"Throughout, when "significant" is used without qualifiers, it means asymptotically significant at the conventional .05 level. 
This interesting result is more fully investigated in another study, ${ }^{12}$ but a possible interpretation is worth giving here. Greater state control of school finances give the state some degree of monopsony power in the purchase of teaching services. Note also that the average teacher salary is increasing in per capita income, decreasing in the share of households headed by females, and decreasing in the share of adults who are college educated. The statistic on the Hausman test, 2.91 , indicates that we cannot reject the null hypothesis that the identifying restrictions are valid at conventional levels of significance.

Table 4 presents selected coefficients from estimating the equation 4 ", which has the studentteacher ratio as the dependent variable. Both the OLS and IV estimates indicate that concentration lowers class size, with the IV regression again estimating a larger effect. By the OLS estimate, a .4 increase in the Herfindahl index of enrollment concentration lowers class size by .7 students; by the IV estimate, a .4 increase in the index lowers class size by 2.7 students. The state's share of school spending appears to have no effect on the student-teacher ratio. However, the student-teacher ratio decreases by 4.6 students for a .10 increase in the share of SMSA households below the poverty level. This may also be an artifact of state and federal programs calibrated on households below the poverty level. The statistic on the Hausman test, 2.18 , indicates that we cannot reject the null hypothesis that the identifying restrictions are valid.

Table 4a shows IV estimates of the coefficient on concentration based on equation 4 ", for various subgroups of SMSAs. The result that student-teacher ratios are decreasing in exogenous concentration appears to come from SMSAs that are relatively compact and have above median populations, population densities and African-American population shares.

Table 5 presents the results of estimating equation 2 , in which the dependent variable is the standard deviation of per-pupil spending in a metropolitan area. This equation tests the idea that increased sorting due to easier choice among districts generates greater disparity in inputs among school

\footnotetext{
12 Hoxby 1994c, "Teachers' Unions and the Effectiveness of Policies Designed to Improve School Quality."
} 
districts. The results indicate no significant relationship between exogenous concentration and the standard deviation of per-pupil spending: the coefficient is insignificantly different from zero and of the "wrong" sign. Note that the standard deviation of per-pupil spending does, however, increase by .3 for a $\$ 1000$ increase in per capita income.

The results of this section reveal a consistent pattern. Within a metropolitan area, greater public school enrollment concentration generates higher per-pupil spending, some of which goes to pay higher teacher salaries and to lower class sizes. Thus, when parents are less able to choose among school districts, they face more expensive districts on average in their metropolitan area. Inputs are only one part of productivity: it remains to be seen whether student performance is also higher in metropolitan areas with higher enrollment concentration. If expense and student performance move together, then metropolitan areas with higher enrollment concentration may simply be able to maintain schools with higher quality and higher expense in equilibrium, perhaps because sorting is restrained in such a way that a higher spending equilibrium is possible. ${ }^{13}$ If we find that student performance is not better in metropolitan areas with higher enrollment concentration, then the more expensive school districts indicate lower productivity.

\section{Public School Enrollment Concentration and Student Performance}

This section tests the second half of the prediction that easier choice among public schools raises school productivity by examining the effect of exogenous concentration on student performance, measured by the students' education attainment and wages at age 24 and by AFQT test scores. The equations,

\footnotetext{
13 Suppose, for instance, that there are two types of households in a metropolitan area, those with a high willingness to pay for public education and those with a low willingness to pay. Suppose also that the high willingness households slightly outnumber the low willingness households. Then, if no sorting is possible and all districts have a high-low ratio equal to the population ratio, then high spending schools prevail everywhere owing to majority rule. If, however, sorting is possible, then low willingness households and high willingness households live in different districts and the districts that contain only low willingness households have low spending schools, lowering the average level of spending in the metropolitan area.
} 
which are estimated both by OLS and IV, are:

$$
\begin{aligned}
& h g c_{i j}=\theta H_{j}+W_{j} \kappa_{i}+W_{i j} \kappa_{2}+v_{j}+v_{i j} \\
& \ln \left(\text { hourly wage } e_{i j}\right)=\theta^{\prime} H_{j}+W_{j} k_{1}^{\prime}+W_{i j} k_{2}^{\prime}+v_{j}^{\prime}+u_{i j}^{\prime} \\
& \text { AFQT percentile score } e_{i j}=\theta^{\prime \prime} H_{j}+W_{j} k_{1}{ }^{\prime \prime}+W_{i j} k_{2}{ }^{\prime \prime}+v_{j}{ }^{\prime \prime}+v_{i j}{ }^{\prime \prime}
\end{aligned}
$$

Variants of equations 3 and $3 "$ are also estimated as linear probability models for various levels of educational attainment (high school diploma by age 19 , any post-secondary school by age 24 , two years of college by age 24 , and 4-year college graduate by age 24 ) and for various levels of the AFQT score (in lowest 10th percentile, in lowest 25 th percentile, in highest 25 th percentile, in highest 10th percentile).

This section also tests whether some students appear to gain in performance at the expense of other students by examining educational attainment and wages for various subgroups of the population. In this way, we may determine whether relatively disadvantaged students lose when choice among public schools is easier. The equations estimated are exemplified by:

$$
\left(\mathrm{hgc}_{\mathrm{ij}} \mid \mathrm{i} \text { belongs to race } \mathrm{k}\right)=\beta_{\mathrm{k}} \mathrm{H}_{\mathrm{j}}+\mathrm{W}_{\mathrm{j}} \alpha_{1 \mathrm{k}}+\mathrm{W}_{\mathrm{ij}} \alpha_{2 \mathrm{k}}+\epsilon_{\mathrm{j}}+\epsilon_{\mathrm{ij}}
$$

Apart from racial subgroups (African-American, Hispanic, white non-Hispanic), estimates are made for students from large and small cities, students whose parents have varying levels of educational attainment (less than high school, exactly high school, more than high school), and male and female students.

This section uses only the observations on public school students because we expect choice among public schools to affect them most. ${ }^{14}$ Each educational attainment and AFQT regression contains observations on 6962 public school students who lived in SMSAs at age 14; the wage regressions contain only 5011 observations because some students have no recorded wages. Note the presence of both an SMSA-specific error term, $\xi$, and an individual-specific error term, $v$. This error structure requires

14 The next section makes use of private school student observations as well. 
feasible generalized least squares (FGLS) ${ }^{15}$ in place of OLS and IV estimation with standard errors adjusted for the common SMSA component. The IV estimates are again identified by intra-county and inter-county rivers (and their squares). The result of Hausman Lagrange multiplier tests for overidentifying restrictions are reported.

The structure of tables 6,8 , and 9 is worth describing here. The first two columns contain, respectively, the FGLS and IV estimates of equations 3, 3' and 3". These regressions do not control for per-pupil spending, teacher salaries, or class size; the estimated coefficients thus represent the effects of concentration as it works directly on student performance and as it works indirectly through changes in school inputs. The third columns include per-pupil spending, teacher salaries, and class size as regressors. The column three coefficients thus represent the effect of concentration on student performance exclusive of its effects on measured school inputs.

Table 6 presents the results of estimating equation 3 whose dependent variable is the student's highest grade completed by age 24 . The FGLS coefficient shows that a .4 increase in the Herfindahl index of public school enrollment concentration (equivalent, recall, to move from ten equal-sized school districts to two equal-sized districts) generates a .2 year decrease in highest grade completed. The IV

is For the $n$ individual observations in SMSA $j \in J$, the variance-covariance matrix is:

$$
Q=\left[\begin{array}{ccccc}
\sigma_{g}^{2}+\sigma_{v}^{2} & \sigma_{v}^{2} & \sigma_{v}^{2} & \ldots & \sigma_{v}^{2} \\
\sigma_{v}^{2} & \sigma_{g}^{2}+\sigma_{v}^{2} & \sigma_{v}^{2} & \ldots & \sigma_{v}^{2} \\
& & \vdots & & \\
\sigma_{v}^{2} & \sigma_{v}^{2} & \sigma_{v}^{2} & \ldots & \sigma_{g}^{2}+\sigma_{v}^{2}
\end{array}\right]
$$

For FGLS, the estimators are:

$$
\hat{\sigma}_{v}^{2}=\frac{\sum_{i} \sum_{j}\left(e_{y}-\bar{e}_{j}\right)^{2}}{(n J-J-K)}, \quad \hat{\sigma}_{E}^{2}=\frac{e^{\prime} e}{J-K}-\frac{\hat{\sigma}_{v}^{2}}{n}
$$

where $e_{i j}$ is the $i j^{\text {th }}$ residual from a least squares dummy variables estimation of equation $(2)$ and $e^{\prime}=$ $\left[e_{11}, \ldots, e_{i j}, \ldots, e_{n j}\right]$. 
estimate shows that .4 increase in the index generates a .3 year decrease in highest grade completed. The statistic on the Hausman test, 1.40, indicates that the identifying restrictions cannot be rejected at conventional levels of significance. These results imply that exogenously higher concentration causes lower educational attainment.

The state's share of public school spending has no significant effect on highest grade completed. Among the background variables for each student, parents' educational attainment is the single most powerful explanatory variable because it acts as a summary statistic for a student's taste for education, genetic ability, skills and information acquired at home, and financial support. The religious denomination controls are included because selection into the public school sector is related to the denomination in which the student was raised. ${ }^{16}$

The column three estimates show that the effect of concentration on student performance is not significantly different when we exclude the indirect effects of concentration on school inputs: a .4 increase in concentration lowers public school students' educational attainment by .2 years. Per-pupil spending and student-teacher ratio in an SMSA have no statisically significant effect on student performance. However, a $10 \%$ increase in average teacher salary is estimated to raise highest grade completed by about .8 of a year.

Table 6a presents IV estimates of the coefficient on concentration based on equation 1 , for various subgroups of students. The result that highest grade completed is decreasing in exogenous concentration appears to come from students who are white and non-Hispanic, and from students who have a parent who is at least a high school graduate. These students are relatively advantaged, so it appears that exogenously lower concentration benefits the advantaged. However, the results in Table 6a show no statistically significant evidence that relatively disadvantaged students perform worse when exogenous concentration is lower.

16 See Hoxby 1994a. 
Table 7 shows IV estimates of the probability of four levels of educational attainment: whether the student has received a high school diploma by age 19, whether a student has attended any postsecondary school by age 24 , whether a student has completed at least two years of college (in a two- or four-year college) by age 24 , and whether a student has been graduated from a four year college by age 24. The first column shows that a .4 increase in concentration generates a .06 decrease in the probability that a public school student receives a high school diploma. Similarly, column two shows that a .4 increase in concentration generates a .02 decrease in the probability that a student attends any postsecondary school. Columns three and four show that a .4 increase in concentration lowers the probability of completing two years of college by .05 and lowers the probability of being graduated from a four-year college by .03 . Thus, exogenous increases in concentration lower students' educational attainment across the entire distribution of achievement.

Tables $7 \mathrm{a}$ and $7 \mathrm{~b}$ show IV estimates of the coefficient on concentration for various student subgroups with, as dependent variables, the probability of graduation from, respectively, high school and college. The estimated coefficients differ interestingly. The result that the probability of high school graduation depends negatively on concentration appears to derive from relatively disadvantaged students: those who have no parent with a high school diploma, those whose highest attaining parent has exactly a high school diploma, African-Americans, and Hispanics. In contrast, the result that the probability of graduation from a four-year college depends negatively on concentration appears to derive from relatively advantaged students: those who have a parent with more than a high school degree, those who are white and non-Hispanic.

Table 8 presents the results of estimating equation $3^{\prime}$ whose dependent variable is the log of the student's hourly wage. The FGLS coefficient shows that a .4 increase in the Herfindahl index of public school enrollment concentration lowers wage by approximately $6 \%$. The IV estimate shows that .4 increase in the index lowers wages by about $5 \%$. The column three estimates show the effects of 
concentration are very much the same whether or not we exclude their indirect effects on student performance through school inputs: a .4 increase in concentration is estimated to raise students' wages by approximately $6 \%$. Average per-pupil spending and student-teacher ratio have no statisically significant effect on wages, but a $10 \%$ increase in teacher salaries raises student's wages by approximately 2\%. ${ }^{17}$ The statistic on the Hausman test, 3.12, indicates that we cannot reject the identifying restrictions at conventional levels of significance.

Table 8a presents IV estimates of the coefficient on concentration with wages as the dependent variables, for various subgroups of students. The result that wages are decreasing in exogenous concentration appears to come from students whose parents have more education, and are white or African-American. This group contains both relatively advantaged and relatively disadvantaged students. It is interesting to note that all the subgroup analyses (Tables $6 \mathrm{a}, 7 \mathrm{a}, 7 \mathrm{~b}$, and $8 \mathrm{a}$ ) show that exogenously lower concentration improves the performance of males more than it improves that of females. A possible explanation is that parents are more willing to pay the costs of sorting themselves into a better school district when the child concerned is male.

Armed Forces Qualifications Test (AFQT) scores are the dependent variables in Tables 9 and 10. All NLSY respondents were asked to take the Armed Services Vocational Aptitude Battery in 1980, from which the AFQT score is derived, and $94 \%$ of respondents completed the battery. ${ }^{18}$ The AFQT score is a summary measure of the student's scores on arithmetic reasoning, word knowledge, paragraph

17 Note that the regressions intentionally do not control for educational attainment. Given that individuals should choose educational attainment optimally to maximize their present discounted value of lifetime earnings, it is earnings which are of interest, not the return to a year of education. Note also that the regressions intentionally control for potential job market experience (the difference between the year the wage was recorded and the year the student left school) rather than actual experience. If a student has an out-of-the-labor-force period or a period of unemployment since leaving school, we do not want to exclude the effect of this period on later wages. Potential job market experience is not a linear transformation of years of schooling since students entered the survey at different ages.

18 Note that, since all respondents took the test in 1980 , the equation is augmented to include indicator variables for the student's age at the time he or she took the test. 
comprehension, and numerical operations. In general, the AFQT score results are only weakly significant or insignificantly different from zero, though consistent with the patterns revealed by educational attainment and wages.

Table 9 shows results of estimating equation $3^{n}$, where the AFQT score is the dependent variable. Greater concentration generates a decrease in scores that is significantly different from zero at only the .36 level (FGLS estimate). Only a student's background appears to have a significant effect on his or her score: parents' highest grade completed, ethnicity, sex, and number of siblings are all significant and have the expected signs.

Table 10 shows IV estimates of the probability of scoring in the lowest 10 th, lowest 25 th, highest 25th, and highest 10 th percentiles. Greater concentration generates insignificant changes in the probabilities that a public school student scores in the lowest 10th or highest 10th percentiles. However, a .4 increase in the Herfindahl index of enrollment concentration increases the probability that a student scores in the lowest 25 th percentile by .03 and decreases the probability that a student scores in the highest 25 th percentile by .04 . It thus appears that exogenous increases in concentration lower students' test scores at both ends of the test score distribution.

Finally, Appendix Table 5 shows IV estimates of variants of equations 3, 3' and 3" where the dependent variables are the inter-quartile ranges of highest grade completed, wages, and AFQT scores for students within each SMSA. These estimates, like those using standard deviations (not shown) as dependent variables, reveal no statistically significant evidence that greater enrollment concentration decreases the variance of student performance within an SMSA.

In summary, this section's results consistently support the hypothesis that exogenously greater enrollment concentration, which makes choice among public school districts more difficult, has a negative effect on student performance. Combined with the results of the previous section, these estimates support the prediction that public schools have lower productivity when concentration is higher. It appears that 
households' being able to choose more easily among public schools elicits greater productivity.

As confirmation of the idea that easier choice among public schools improves outcomes for advantaged students at the expense of disadvantaged students through increased sorting, this section's results are a mixed lot. For highest grade completed, probability of graduation from a four-year college, and wages, relatively advantaged students appear to be the main beneficiaries of lower concentration. There is, however, no evidence that relatively disadvantaged students are hurt. Moreover, for the probability of high school graduation, relatively disadvantaged students appear to be the main beneficiaries. Overall, it is reasonable to conclude that lower concentration does generate more sorting, but that the increase in sorting has neither simple nor dramatic effects on student performance.

\section{Public School Enrollment Concentration and Private Schools}

This section tests the prediction that private schools enroll a larger share of students in metropolitan areas that have greater public school enrollment concentration. The equation, which is estimated by both OLS and IV is:

$$
\text { private share of enrollment }{ }_{j}=\pi H_{j}+W_{j} \rho+\omega_{j}
$$

Note, particularly in this application, that $\mathrm{W}_{\mathrm{j}}$ includes population shares for eight major demoninations. These shares are especially important in this equation because we wish to examine the portion of private school enrollment that is endogenous to public school enrollment concentration. By controlling for denominational prevalence, we eliminate the main exogenous determinant of private school enrollment (and possible confusion between the effects of enrollment concentration and denominational prevalence). ${ }^{19}$

Table 11 presents the results of estimating equation 5. Both the FGLS and IV estimates show

19 There is, in any case, no significant correlation between public school enrollment concentration and the Catholic population share (by far the most important denomination for determining private school enrollment). 
that a .4 increase in Herfindahl index of public school enrollment concentration raises the share of SMSA enrollment in private schools by .02 . This is a large increase in the private school enrollment share, as the mean share for an SMSA is only .10. The state's share of school expenditure appears to have no significant effect on the private school enrollment share. The private school share is increasing, however, in the Catholic population share and per capita income.

Since concentration appears to affect the sorting of students into private schools, potential for sample selection bias exists when we look only at the students who remain in public schools. If, for instance, one of the effects of greater public school enrollment concentration is making abler students more likely to attend private schools, then public school students' performance will be worse in concentrated SMSAs simply because selection into the public school student sample is negatively correlated with ability. Such sample selection bias could potentially explain the student performance results of the previous section. Table 12 presents IV re-estimates of equations $3,3^{\prime}$ and $3^{\prime \prime}$, including private school students in the sample to eliminate any effects of sample selection. The table shows that results based on the entire sample of students (public and private) are insignificantly different from those based on public school students only. A .4 increase in concentration causes highest grade completed to fall by 2 . years, causes wages to fall by $6 \%$, and causes the probability of scoring in the highest 25 th percentile to fall by .02 .

Private school enrollment could also potentially explain the result that per-pupil spending is increasing in public school enrollment concentration. If greater enrollment concentration induces students to attend private school and the resulting decrease in per-pupil school revenue is smaller than current perpupil spending, then per-pupil spending will increase with each student induced to attend private school. Table 13, which re-estimates equations 4, 4' and 4" by FGLS controlling for the private enrollment share, tests whether private school enrollment explains part or all of the effect of concentration on school inputs. The table shows that the estimated coefficients on concentration are not changed significantly when we 
control for the private school enrollment share. A .4 increase in concentration raises per-pupil spending by $\$ 191$ (compare to $\$ 203$ ), raises teacher salaries by $2 \%$ (compare to $2 \%$ ), and lowers the studentteacher ratio by .6 (compare to .6).

\section{Conclusions}

The previous sections present several pieces of evidence relevant to the debate about enabling parents to choose more easily among public school districts. I have shown that the increase in school choice generated by changing a metropolitan area from two equal-sized school districts to ten equal-sized school districts lowers per-pupil spending by $\$ 219$ while it improves students' educational attainment by .3 years, wages by $5 \%$, and the probability of achieving a top quartile AFQT score by $2 \%$. The competition among public schools that is generated by increased choice appears to increase productivity in such a way that costs are reduced while student performance is improved.

The results also appear to support the prediction that increased choice results in increased sorting of students among schools. There is general evidence that relatively advantaged students benefit disproportionately from the increased sorting. This evidence is contradicted when the probability of high school graduation is used as the measure of student performance: it then appears that relatively disadvantaged students benefit disproportionately from increased sorting. Also, improvements in student performance are spread over the entire distribution of students, ranked by their educational attainment or test scores. The variance of student performance in an SMSA does not vary significantly with concentration. The evidence on relative benefits of lower concentration is, thus, mixed. There is no statistically significant evidence that disadvantaged students actually lose due to increased sorting.

All the results just discussed depend on variation in public school district enrollment concentration that is exogenous to school conduct and performance. Natural boundaries, in the form of rivers, are strongly correlated instruments for enrollment concentration. The IV estimates allow a causal 
interpretation of the relationship between concentration and school productivity.

Relevant to the modeling of local public goods provision, the previous sections confirm that local governments behave strategically. They are less likely to produce local public goods at minimum cost when market structure makes it difficult or costly for households to shift their demand among local governments. Optimal local government size cannot merely be modeled as a function of the demands for and the production functions of local public goods. Giving local governments larger shares of a metropolitan area will mean lower productivity in local public goods production.

By reducing the ease of choice among public school districts, greater enrollment concentration raises the share of students who attend private schools. The increase in public school choice generated by changing an SMSA from two to ten school districts causes the share of students in private schools to fall by a sizeable 2 percentage points.

For improving student performance, how does competition between public schools compare to competition between public and private schools? Consider a metropolitan area with one large public school district and no private schools. Suppose we induce a .1 reduction in Herfindahl index of public school enrollment concentration by creating a second public school district that takes $5.25 \%$ of the students from the initial district. For this change in public school enrollment concentration, we improve the educational attainment of public school students by .07 years and improve the wages of public school students by $1.3 \%$. Now, suppose that we instead send $5.25 \%$ of the students to private schools. Using this change, we improve public school students' educational attainment by .14 years and wages by $2.5 \% .20$ Thus, for an approximately equal movement of students, competition from private schools has approximately double the positive effect on public school students that competition between public schools has. $^{21}$

20 These estimates are based on results in Hoxby 1994a.

21 I do not attempt to compare the effects of a program that allows only public school choice with the effects of an equally costly program that allows choice between public and private schools as it is difficult to estimate costs: vouchers are transfers between schools rather than overall increases in school spending. 


\section{Bibliography}

Aker, John S. and Irwin Garfinkel. (1977) "School Expenditures and Economic Returns to Schooling." Journal of Human Resources, 12(4), 460-81.

Akin, J. and M. Lea. (1982) "Microdata Estimation of School Expenditure Levels: An Alternative to the Median Voter Approach." Public Choice, 38, 113-28.

Basmann, R. (1960) "On Finite Sample Distributions of Generalized Classical Linear Identifiability Test Statistics." Journal of the American Statistical Association. Vol. 55, 650-659.

Behrman, Jere R. and Birdsall, Nancy. (1983) "The Quality of Schooling: Quantity Alone is Misleading." American Economic Review, 73, 928-46.

Benabou, Roland. (1993a) "Workings of a City: Location, Education, and Production." The Quarterly Journal of Economics, August 1993, 619-52.

---. (1993b) "Heterogeneity, Stratification, and Growth." NBER Working Paper No. 4311, April 1993.

Benson, Charles. (1978) The Economics of Public Education. 3rd Edition. Boston: Houghton-Mifflin.

Borland, Melvin V. and Roy M. Howsen. (1992) "Student Academic Achievement and the Degree of Market Concentration in Education." Economics of Education Review, Vol. II, No. 1, 31-39.

Bowles, Samuel. (1970) "Towards an Education Production Function" in Education, Income, and Human Capital. ed.: W. Lee Hansen. New York: NBER, 11-60.

Bound, John, David A. Jaeger, and Regina Baker. (1993) "The Cure can be Worse than the Disease: A Cautionary Tale Regarding Instrumental Variables." NBER Technical Working Paper No. 137.

Card, David and Alan Krueger. (1992a) "Does School Quality Matter? Returns to Education and the Characteristics of Public Schools in the United States." Journal of Political Economy, 100.1, 140.

----. (1992b) "School Quality and Black-White Relative Earnings: A Direct Assessment." Quarterly Journal of Economics, 107.

Chubb, John E. and Terry M. Moe. (1990) Politics, Markets, and America's Schools. Washington, D.C.: The Brookings Institution.

Clune, William, and John White (eds.) (1990) Choice and Control in American Education. Vol. 2: The Practice of Choice, Decentralization, and School Restructuring. London: FalmerPress.

Coleman, James S. and Thomas Hoffer. (1987) Public and Private High Schools. New York: Basic Books.

Coleman, James S., Thomas Hoffer, and Sally Kilgore. (1982) High School Achievement: Public, Catholic, and Private Schools Compared. New York: Basic Books. 
Courant, P.N., E.M. Gramlich, and D.L. Rubinfeld. (1979) "Public Employee Market Power and the Level of Government Spending." American Economic Review, 69, 806-17.

Eberts, Randall W. and T.J. Gronberg. (1981) "Jurisdictional Homogeneity and the Tiebout Hypothesis." Journal of Urban Economics, 10, 227-39.

---, E.K. Schwartz, and Joe A. Stone. (1990) "School Reform, School Size, and Student Achievement." Economic Review Federal Reserve Bank of Cleveland, 26.2, 2.

Epple, Dennis and Richard Romano. (1993) "Competition between Private and Public Schools, Vouchers, and Peer Group Effects." Carnegie Mellon University mimeo.

Epple, Dennis, R. Filimon, and T. Romer. (1984) "Equilibrium among Local Jurisdictions: Toward an Integrated Treatment of Voting and Residential Choice" Journal of Public Economics, 17,281308.

--.. (1983) "Housing, Voting, and Moving: Equilibrium in a Model of Local Public Goods with Multiple Jurisdictions" in J. Henderson, ed. Research in Urban Economics, 3, 59-90.

Epple, Dennis and A. Zelnitz. (1981) "The Implications of Competition among Jurisdictions: Does Tiebout Need Politics?" Journal of Political Economy, 89, 1197-1217.

Griliches, Zvi and William M Mason. (1972) "Education, Income, and Ability." Journal of Political Economy, 80.3.2, S74-S103.

Hanushek, Eric A. (1989) "The Impact of Differential Expenditure on School Performance." Educational Researcher, May, 45-51, 62.

--- (1986) "The Economics of Schooling: Production and Efficiency in Public Schools." Journal of Economic Literature, 24, 1141-1177.

---. (1979) "Conceptual and Empirical Issues in the Estimation of Education Production Functions." Journal of Human Resources, 14(3), 351-88.

Hausman, J. (1983) "Specification and Estimation of Simultaneous Equation Models," in Z. Griliches and M. Intrilligator, eds., Handbook of Econometrics, Amsterdam: North Holland.

Johnson, George E. and Frank P. Stafford. (1973) "Social Returns to Quantity and Quality of Schooling." Journal of Human Resources, 8, 139-55.

Kirkpatrick, David W. (1990) Choice in Schooling. Chicago: Loyala University Press.

Moulton, Brent R. (1986) "Random Group Effects and the Precision of Regression Estimates." Journal of Econometrics, 32, 385-97.

Murnane, Richard J. (1984) "A Review Essay - Comparisons of Public and Private Schools: Lessons from the Uproar." Journal of Human Resources 19(2), 263-77.

Nelson, C. R. and R. Startz. (1990) "Some Further Results on the Exact Small Sample Properties of the Instrumental Variables Estimator." Econometrica, 58, 967-976. 
----. (1990) "The Distribution of the Instrumental Variables Estimator and its t-Ratio when the Instrument is a Poor One." Journal of Business, 20.

Pack, H. and J.R. Pack. (1977) "Metropolitan Fragmentation and Suburban Homogeneity." Urban Studies, 14, 191-201.

Peltzman, Sam. (1992) "The Political Economy of the Decline of American Public Education." University of Chicago, Center for the Study of the Economy and the State Working Paper No. 78.

Rosen, Sherwin. (1977) "Human Capital: A Survey of Economic Research" in Research in Labor Economics, Vol. 1, ed. Ronald G. Ehrenberg. Greenwich, Conn.: JAI Press. 3-39.

Rubinfeld, Daniel L. (1980) "On the Economics of Voter Turnout in Local School Elections." Public Choice, 35, 315-331.

---. (1977) "Voting in a Local School Election: A Micro Analysis." Review of Economics and Statistics, 59, 30-42.

---, P. Shapiro, and J. Roberts. (1988) "Tiebout Bias and the Demand for Local Public Schooling." Review of Economics and Statistics, 70.

Staiger, Douglas and James H. Stock. (1993) "Asymptotics for Instrumental Variables Regressions with Weakly Correlated Instruments" mimeo, Kennedy School of Government, Harvard University, and the NBER.

Summers, Anita and Barbara Wolfe. (1977) "Do Schools Make a Difference?" American Economic Review, 67.4, 639-52.

Tiebout, Charles. (1956) "A Pure Theory of Local Public Expenditures." Journal of Political Economy, 64, 416-24.

U.S. Department of Education. (1992) Office of Educational Research and Improvement. National Center for Education Statistics. Comparisons of Public and Private Schools, 1991-92. Washington, D.C.: U.S. Government Printing Office.

---. (1992) Digest of Education Statistics 1991. Washington, D.C.: U.S. Government Printing Office.

-.-. (1992) Public and Private Elementary and Secondary Education Statistics: School Year 1991-92. Washington, D.C.: U.S. Government Printing Office.

Welch, Finis. (1966) "Measurement of the Quality of Schooling." American Economic Review Papers and Proceedings, 56, 379-92. 
Table 1

First Stage Regression for Herfindahl Index of Public School Enrollment Concentration (Selected Coefficients)

\begin{tabular}{||cc||}
\hline & \multicolumn{2}{|c|}{$\begin{array}{c}\text { Dependent Variable } \\
\text { Herfindahl Index of Public School } \\
\text { Enrollment Concentration }\end{array}$} \\
\hline Number of Intra-County Rivers in SMSA & -.029 \\
& $(.007)$ \\
Number of Intra-County Rivers in SMSA & .0008 \\
Squared & $(.0003)$ \\
Number of Inter-County Rivers in SMSA & -.050 \\
& $(.018)$ \\
Number of Inter-County Rivers in SMSA & .003 \\
Squared & $(.001)$ \\
\hline
\end{tabular}

Covariates not shown in table: land area of SMSA, squared land area of SMSA, total population of SMSA, share of SMSA population classified as urban, SMSA per capita income, share of SMSA households with income below poverty level, share of SMSA households with $\$ 10,000-20,000$ income, share of SMSA households with $\$ 20,000$ 30,000 income, share of SMSA households with $\$ 30,000-40,000$ income, share of SMSA households with $\$ 50,000$ or more income, share of SMSA households who receive transfer payments, share of SMSA households headed by females, share of SMSA population who are African-American, share of SMSA population who are Hispanic, share of SMSA population who are Asian, share of SMSA population who are Native American, share of SMSA adult population who have at least 12 years of education, share of SMSA adult population who have at least 16 years of education, Gini coefficient on SMSA household incomes, Herfindahl index of SMSA racial homogeneity, shares of SMSA population who are Catholic, Lutheran, Baptist, Episcopalian, Friends, Jewish, Methodist, and Presbyterian adherents. 
Table 2

Public School Spending and Market Concentration in Public Schooling

Dependent Variable: Per Pupil Spending in Public Schools in SMSA (\$1982)

(mean \$2139, standard deviation \$437)

\begin{tabular}{||ccc||}
\hline & OLS & IV \\
\hline SMSA Herfindahl Index of & 508 & 548 \\
Public School Enrollment Conc & $(124)$ & $(232)$ \\
Share of Public School Spending & 106 & 359 \\
from State Funds & $(207)$ & $(270)$ \\
SMSA Land Area & 5 & 0.5 \\
(Hundreds of Square Miles) & $(2)$ & $(3)$ \\
SMSA Land Area Squared & $-1.6 \mathrm{e}-4$ & $-2.1 \mathrm{e}-5$ \\
(Hundreds of Square Miles) & $(9.6 \mathrm{e}-5)$ & $(1.3 \mathrm{e}-4)$ \\
Total SMSA Population & -4 & -20 \\
(Millions) & $(26)$ & $(29)$ \\
Share of SMSA Population & -1 & -139 \\
Urban & $(295)$ & $(335)$ \\
SMSA Per Capita Income & 42 & 80 \\
(Thousands) & $(22)$ & $(42)$ \\
Share of SMSA Households with & 5079 & 4113 \\
Income Below Poverty Level & $(2390)$ & $(2638)$ \\
Share of SMSA Households & -6071 & -7774 \\
Headed by Females & $(2767)$ & $(3268)$ \\
Share of SMSA Adult Population & 1388 & 613 \\
with 16+ Years of Education & $(911)$ & $(1068)$ \\
Gini Coefficient on SMSA & -5472 & -496 \\
Households Incomes & $(4900)$ & $(457)$ \\
U.S. Census Region Indicator & yes & yes \\
Variables & & \\
Hausman Lagrange Mult Test of & & 3.70 \\
Overid Restrictns Asymp Chi-Sq & & \\
Statistic (cum prob in paren) & & \\
\hline & & \\
\hline
\end{tabular}

Note: Standard errors in parentheses, except as noted. 264 observations (SMSAs).

Covariates not shown in table: share of SMSA households with $\$ 10,000-20,000$ income, share of SMSA households with $\$ 20,000-30,000$ income, ..., share of SMSA households with $\$ 50,000$ or more income, share of SMSA households who receive transfer payments, share of SMSA population who are African-American, share of SMSA population who are Hispanic, share of SMSA population who are Asian, share of SMSA population who are Native American, share of SMSA adult population who have at least 12 years of education, Herfindahl index of SMSA racial homogeneity, shares of SMSA population who are Catholic, Lutheran, Baptist, Episcopalian, Friends, Jewish, Methodist, and Presbyterian adherents. 
Table 2a

Effect of Market Concentration on Public School Spending

Entries are Estimated Coefficients on Market Concentration in Public Schooling Dependent Variable is Per Pupil Spending in Public Schools in SMSA (\$1982)

Same Specification as Table 2, for Various Subgroups of SMSAs

\begin{tabular}{|c|c|c|}
\hline Sample & No. of Observations & $\begin{array}{l}\text { IV Estimated Coefficient } \\
\text { on SMSA Herfindahl Index of } \\
\text { Public School Enrollment Conc }\end{array}$ \\
\hline All SMSAs & 264 & $\begin{array}{c}548 \\
(232)\end{array}$ \\
\hline $\begin{array}{l}\text { SMSAs w/ Large Populations } \\
(>279,780=\text { median })\end{array}$ & 134 & $\begin{array}{c}545 \\
(667)\end{array}$ \\
\hline $\begin{array}{l}\text { SMSAs w/ Small Population } \\
(<279,780=\text { median })\end{array}$ & 130 & $\begin{array}{c}455 \\
(292)\end{array}$ \\
\hline $\begin{array}{l}\text { SMSAs w/ Expansive Land } \\
\text { Areas } \\
\text { (> } 1429 \text { sq } \mathrm{ml}=\text { median })\end{array}$ & 133 & $\begin{array}{l}-1195 \\
(1303)\end{array}$ \\
\hline $\begin{array}{l}\text { SMSAs w/ Compact Land Areas } \\
(<1429 \mathrm{sq} \mathrm{ml}=\text { median })\end{array}$ & 131 & $\begin{array}{c}816 \\
(294)\end{array}$ \\
\hline $\begin{array}{c}\text { SMSAs w/ High Pop Densities } \\
(>226.1 \text { people/sq } \mathrm{ml}= \\
\text { median })\end{array}$ & 131 & $\begin{array}{l}1686 \\
(516)\end{array}$ \\
\hline $\begin{array}{c}\text { SMSAs w/ Low Pop Densities } \\
(<226.1 \text { people/sq } \mathrm{ml}= \\
\text { median })\end{array}$ & 133 & $\begin{array}{l}-1850 \\
(1244)\end{array}$ \\
\hline $\begin{array}{l}\text { SMSAs w/ Large African- } \\
\text { American Population Shares } \\
(>6.9 \% \text { of pop }=\text { median) }\end{array}$ & 134 & $\begin{array}{c}596 \\
(209)\end{array}$ \\
\hline $\begin{array}{l}\text { SMSAs w/ Small African- } \\
\text { American Population Shares } \\
(<6.9 \% \text { of pop }=\text { median })\end{array}$ & 130 & $\begin{array}{l}-2109 \\
(2046)\end{array}$ \\
\hline
\end{tabular}

Note: Standard errors in parentheses, except as noted. Dependent variable has mean $\$ 2139$, standard deviation \$437. Unit of observation is an SMSA.

The equations estimated in this table are identical to that of Table 2, IV column. Only the sample of SMSAs over which the equations are estimated differs. See Table 2 for covariates. 
Table 3

Teacher Salaries and Market Concentration in Public Schooling

Dependent Variable: Ln(Avg Teacher Salary) in SMSA Public Schools (\$1982)

(mean 9.74, standard deviation .17)

\begin{tabular}{||ccc||}
\hline & OLS & IV \\
\hline SMSA Herfindahl Index of & .05 & .18 \\
Public School Enrollment Conc & $(.02)$ & $(.05)$ \\
Share of Public School Spending & -.10 & -.12 \\
from State Funds & $(.02)$ & $(.02)$ \\
SMSA Land Area & $1.0 \mathrm{e}-4$ & $1.4 \mathrm{e}-3$ \\
(Hundreds of Square Miles) & $(2.2 \mathrm{e}-4)$ & $(4.1 \mathrm{e}-4)$ \\
SMSA Land Area Squared & $-9.0 \mathrm{e}-9$ & $-4.7 \mathrm{e}-8$ \\
(Hundreds of Square Miles) & $(7.4 \mathrm{e}-9)$ & $(1.2 \mathrm{e}-8)$ \\
Total SMSA Population & $4.7 \mathrm{e}-3$ & $1.0 \mathrm{e}-3$ \\
(Millions) & $(1.3 \mathrm{e}-3)$ & $(1.7 \mathrm{e}-3)$ \\
Share of SMSA Population & .06 & .11 \\
Urban & $(.03)$ & $(.04)$ \\
Ln(SMSA Per Capita Income) & .91 & .95 \\
Share of SMSA Households with & $(.13)$ & $(.15)$ \\
Income Below Poverty Level & -.07 & .46 \\
Share of SMSA Households & $(.26)$ & $(.30)$ \\
Headed by Females & -.85 & -.53 \\
Share of SMSA Adult Population & $(.33)$ & $(.35)$ \\
with 16+ Years of Education & -.25 & -.30 \\
Gini Coefficient on SMSA & $(.11)$ & $(.11)$ \\
Households Incomes & -.59 & .16 \\
U.S. Census Region Indicator & $(.51)$ & $(.57)$ \\
Variables & yes & yes \\
Hausman Lagrange Mult Test of & & 2.91 \\
Overid Restrictns Asymp Chi-Sq & & $(.55)$ \\
Statistic (cum prob in paren) & & \\
\hline \hline
\end{tabular}

Note: Standard errors in parentheses, except as noted. 264 observations (SMSAs).

Covariates not shown in table: share of SMSA households with $\$ 10,000-20,000$ income, share of SMSA households with $\$ 20,000-30,000$ income, ..., share of SMSA households with $\$ 50,000$ or more income, share of SMSA households who receive transfer payments, share of SMSA population who are African-American, share of SMSA population who are Hispanic, share of SMSA population who are Asian, share of SMSA population who are Native American, share of SMSA adult population who have at least 12 years of education, Herfindahl index of SMSA racial homogeneity, shares of SMSA population who are Catholic, Lutheran, Baptist, Episcopalian, Friends, Jewish, Methodist, and Presbyterian adherents. 
Table 4

Student-Teacher Ratio and Market Concentration in Public Schooling

Dependent Variable: Student-Teacher Ratio in Public Schools in SMSA

(mean 16.8, standard deviation 3.9)

\begin{tabular}{|c|c|c|}
\hline & OLS & IV \\
\hline $\begin{array}{l}\text { SMSA Herfindahl Index of } \\
\text { Public School Enrollment Conc }\end{array}$ & $\begin{array}{l}-1.7 \\
(.8)\end{array}$ & $\begin{array}{l}-6.8 \\
(3.0)\end{array}$ \\
\hline $\begin{array}{l}\text { Share of Public School Spending } \\
\text { from State Funds }\end{array}$ & $\begin{array}{c}.6 \\
(1.9)\end{array}$ & $\begin{array}{l}3.0 \\
(2.6)\end{array}$ \\
\hline $\begin{array}{c}\text { SMSA Land Area } \\
\text { (Hundreds of Square Miles) }\end{array}$ & $\begin{array}{l}-.02 \\
(.02)\end{array}$ & $\begin{array}{l}-.05 \\
(.03)\end{array}$ \\
\hline $\begin{array}{l}\text { SMSA Land Area Squared } \\
\text { (Hundreds of Square Miles) }\end{array}$ & $\begin{array}{c}5.5 e-7 \\
(8.1 e-7)\end{array}$ & $\begin{array}{l}1.5 e-6 \\
(1.0 e-6)\end{array}$ \\
\hline $\begin{array}{c}\text { Total SMSA Population } \\
\text { (Millions) }\end{array}$ & $\begin{array}{l}.2 \\
(.2)\end{array}$ & $\begin{array}{l}.2 \\
(.2)\end{array}$ \\
\hline $\begin{array}{c}\text { Share of SMSA Population } \\
\text { Urban }\end{array}$ & $\begin{array}{c}-.7 \\
(2.5)\end{array}$ & $\begin{array}{c}.4 \\
(2.8)\end{array}$ \\
\hline $\begin{array}{l}\text { SMSA Per Capita Income } \\
\text { (Thousands) }\end{array}$ & $\begin{array}{r}-.4 \\
(.3)\end{array}$ & $\begin{array}{l}-.2 \\
(.3)\end{array}$ \\
\hline $\begin{array}{l}\text { Share of SMSA Households with } \\
\text { Income Below Poverty Level }\end{array}$ & $\begin{array}{l}-46.4 \\
(20.0)\end{array}$ & $\begin{array}{l}-52.6 \\
(21.5)\end{array}$ \\
\hline $\begin{array}{l}\text { Share of SMSA Households } \\
\text { Headed by Females }\end{array}$ & $\begin{array}{c}21.0 \\
(23.9)\end{array}$ & $\begin{array}{c}10.7 \\
(26.1)\end{array}$ \\
\hline $\begin{array}{l}\text { Share of SMSA Adult Population } \\
\text { with } 16+\text { Years of Education }\end{array}$ & $\begin{array}{c}.8 \\
(8.1)\end{array}$ & $\begin{array}{l}-4.3 \\
(9.1)\end{array}$ \\
\hline $\begin{array}{l}\text { Gini Coefficient on SMSA } \\
\text { Households lncomes }\end{array}$ & $\begin{array}{c}7.3 \\
(42.9)\end{array}$ & $\begin{array}{c}21.7 \\
(46.1)\end{array}$ \\
\hline $\begin{array}{c}\text { U.S. Census Region Indicator } \\
\text { Variables }\end{array}$ & yes & yes \\
\hline $\begin{array}{l}\text { Hausman Lagrange Mult Test of } \\
\text { Overid Restrictns Asymp Chi-Sq } \\
\text { Statistic (cum prob in paren) }\end{array}$ & & $\begin{array}{l}2.18 \\
(.55)\end{array}$ \\
\hline
\end{tabular}

Note: Standard errors in parentheses, except as noted. 264 observations (SMSAs).

Covariates not shown in table: share of SMSA households with $\$ 10,000-20,000$ income, share of SMSA households with $\$ 20,000-30,000$ income, ..., share of SMSA households with $\$ 50,000$ or more income, share of SMSA households who receive transfer payments, share of SMSA population who are African-American, share of SMSA population who are Hispanic, share of SMSA population who are Asian, share of SMSA population who are Native American, share of SMSA adult population who have at least 12 years of education, Herfindahl index of SMSA racial homogeneity, shares of SMSA population who are Catholic, Lutheran, Baptist, Episcopalian, Friends, Jewish, Methodist, and Presbyterian adherents. 
Table 4a

Effect of Market Concentration on Student-Teacher Ratio

Entries are Estimated Coefficients on Market Concentration in Public Schooling Dependent Variable is Student-Teacher Ratio in Public Schools in SMSA Same Specification as Table 4, for Various Subgroups of SMSAs

\begin{tabular}{|c|c|c|}
\hline Sample & No. of Observations & $\begin{array}{l}\text { IV Estimated Coefficient } \\
\text { on SMSA Herfindahl Index of } \\
\text { Public School Enrollment Conc }\end{array}$ \\
\hline All SMSAs & 264 & $\begin{array}{l}-6.8 \\
(3.0)\end{array}$ \\
\hline $\begin{array}{l}\text { SMSAs w/ Large Populations } \\
(>279,780=\text { median })\end{array}$ & 134 & $\begin{array}{l}-21.2 \\
(10.4)\end{array}$ \\
\hline $\begin{array}{l}\text { SMSAs w/ Small Population } \\
(<279,780=\text { median })\end{array}$ & 130 & $\begin{array}{l}-3.1 \\
(2.3)\end{array}$ \\
\hline $\begin{array}{l}\text { SMSAs w/ Expansive Land } \\
\text { Areas } \\
(>1429 \mathrm{sq} \mathrm{ml}=\text { median })\end{array}$ & 133 & $\begin{array}{c}5.4 \\
(3.7)\end{array}$ \\
\hline $\begin{array}{l}\text { SMSAs w/ Compact Land Areas } \\
\qquad(<1429 \mathrm{sq} \mathrm{ml}=\text { median })\end{array}$ & 131 & $\begin{array}{l}-29.9 \\
(7.7)\end{array}$ \\
\hline $\begin{array}{c}\text { SMSAs w/ High Pop Densities } \\
(>226.1 \text { people } / \mathrm{sq} \mathrm{ml}= \\
\text { median })\end{array}$ & 131 & $\begin{array}{r}-16.8 \\
(7.2)\end{array}$ \\
\hline $\begin{array}{c}\text { SMSAs w/ Low Pop Densities } \\
(<226.1 \text { people/sq } \mathrm{ml}= \\
\text { median })\end{array}$ & 133 & $\begin{array}{l}4.23 \\
(2.2)\end{array}$ \\
\hline $\begin{array}{l}\text { SMSAs w/ Large African- } \\
\text { American Population Shares } \\
(>6.9 \% \text { of pop }=\text { median })\end{array}$ & 134 & $\begin{array}{l}-10.5 \\
(3.1)\end{array}$ \\
\hline $\begin{array}{l}\text { SMSAs } w / \text { Small African- } \\
\text { American Population Shares } \\
(<6.9 \% \text { of pop }=\text { median })\end{array}$ & 130 & $\begin{array}{l}-1.4 \\
(3.4)\end{array}$ \\
\hline
\end{tabular}

Note: Standard errors in parentheses, except as noted. Dependent variable has mean 16.8, standard deviation 3.9. Unit of observation is an SMSA.

The equations estimated in this table are identical to that of Table 4, IV column. Only the sample of SMSAs over which the equations are estimated differs. See Table 4 for covariates. 
Table 5

Disparity in Public School Spending and Market Concentration in Public Schooling

Dependent Variable: Std.Dev.(Per Pupil Spending in Public Schools in SMSA \$1982)

\begin{tabular}{|c|c|c|}
\hline & OLS & IV \\
\hline $\begin{array}{l}\text { SMSA Herfindahl Index of } \\
\text { Public School Enrollment Conc }\end{array}$ & $\begin{array}{l}.13 \\
(.20)\end{array}$ & $\begin{array}{c}1.07 \\
(1.42)\end{array}$ \\
\hline $\begin{array}{l}\text { Share of Public School Spending } \\
\text { from State Funds }\end{array}$ & $\begin{array}{l}-.25 \\
(.28)\end{array}$ & $\begin{array}{l}-.44 \\
(.40)\end{array}$ \\
\hline $\begin{array}{c}\text { SMSA Land Area } \\
\text { (Hundreds of Square Miles) }\end{array}$ & $\begin{array}{c}6.7 e-5 \\
(3.8 e-5)\end{array}$ & $\begin{array}{r}1.0 e-4 \\
(6.8 e-5)\end{array}$ \\
\hline $\begin{array}{l}\text { SMSA Land Area Squared } \\
\text { (Hundreds of Square Miles) }\end{array}$ & $\begin{array}{l}-1.4 \mathrm{e}-9 \\
(1.4 \mathrm{e}-9)\end{array}$ & $\begin{array}{l}-2.5 e-9 \\
(2.3 e-9)\end{array}$ \\
\hline $\begin{array}{c}\text { Total SMSA Population } \\
\text { (Millions) }\end{array}$ & $\begin{array}{l}-1.7 e-4 \\
(1.1 e-4)\end{array}$ & $\begin{array}{l}-4.1 e-5 \\
(2.1 e-4)\end{array}$ \\
\hline $\begin{array}{c}\text { Share of SMSA Population } \\
\text { Urban }\end{array}$ & $\begin{array}{l}.46 \\
(.42)\end{array}$ & $\begin{array}{l}.29 \\
(.48)\end{array}$ \\
\hline $\begin{array}{l}\text { SMSA Per Capita Income } \\
\text { (Thousands) }\end{array}$ & $\begin{array}{c}.33 \\
(.05)\end{array}$ & $\begin{array}{l}.32 \\
(.05)\end{array}$ \\
\hline $\begin{array}{l}\text { Share of SMSA Households with } \\
\text { Income Below Poverty Level }\end{array}$ & $\begin{array}{l}2.26 \\
(3.50)\end{array}$ & $\begin{array}{l}5.18 \\
(5.99)\end{array}$ \\
\hline $\begin{array}{l}\text { Share of SMSA Households } \\
\text { Headed by Females }\end{array}$ & $\begin{array}{c}-5.63 \\
(4.28)\end{array}$ & $\begin{array}{r}-8.88 \\
(6.22)\end{array}$ \\
\hline $\begin{array}{l}\text { Share of SMSA Adult Population } \\
\text { with } 16+\text { Years of Education }\end{array}$ & $\begin{array}{c}-.40 \\
(1.34)\end{array}$ & $\begin{array}{l}-.27 \\
(1.42)\end{array}$ \\
\hline $\begin{array}{l}\text { Gini Coefficient on SMSA } \\
\text { Households Incomes }\end{array}$ & $\begin{array}{l}-2.08 \\
(7.11)\end{array}$ & $\begin{array}{l}-2.31 \\
(7.56)\end{array}$ \\
\hline $\begin{array}{c}\text { U.S. Census Region Indicator } \\
\text { Variables }\end{array}$ & yes & yes \\
\hline $\begin{array}{l}\text { Hausman Lagrange Mult Test of } \\
\text { Overid Restrictns Asymp Chi-Sq } \\
\text { Statistic (cum prob in paren) }\end{array}$ & & $\begin{array}{l}2.71 \\
(.43)\end{array}$ \\
\hline
\end{tabular}

Note: Standard errors in parentheses, except as noted. 264 observations (SMSAs).

Covariates not shown in table: share of SMSA households with $\$ 10,000-20,000$ income, share of SMSA households with $\$ 20,000-30,000$ income, ..., share of SMSA households with $\$ 50,000$ or more income, share of SMSA households who receive transfer payments, share of SMSA population who are African-American, share of SMSA population who are Hispanic, share of SMSA population who are Asian, share of SMSA population who are Native American, share of SMSA adult population who have at least 12 years of education, Herfindahl index of SMSA racial homogeneity, shares of SMSA population who are Catholic, Lutheran, Baptist, Episcopalian, Friends, Jewish, Methodist, and Presbyterian adherents. 
The Following Note Applies to Tables 6-10.

Covariates not shown in tables: share of SMSA population classified as urban, share of SMSA households with income below poverty level, share of SMSA households with $\$ 10,000-20,000$ income, share of SMSA households with $\$ 20,000-30,000$ income, share of SMSA households with $\$ 30,000-40,000$ income, share of SMSA households with $\$ 50,000$ or more income, share of SMSA households who receive transfer payments, share of SMSA households headed by females, share of SMSA population who are African-American, share of SMSA population who are Hispanic, share of SMSA population who are Asian, share of SMSA population who are Native American, share of SMSA adult population who have at least 12 years of education, share of SMSA adult population who have at least 16 years of education, Gini coefficient on SMSA household incomes, Herfindahl index of SMSA racial homogeneity, shares of SMSA population who are Catholic, Lutheran, Baptist, Episcopalian, Friends, Jewish, Methodist, and Presbyterian adherents; enrollment size of student's school and its square, indicator variables for religious denomination in which student was raised; birth order of student. 
Table 6

Educational Attainment and Market Concentration in Public Schooling

Dependent Variable: Highest Grade Completed by Public Schl Student Age 24 (mean 12.3, standard deviation 2.1)

\begin{tabular}{|c|c|c|c|}
\hline & FGLS & $\begin{array}{c}\text { IV } \\
\text { (adj std errs) }\end{array}$ & $\begin{array}{c}\text { FGLS } \\
\text { Controls: School Characteristics }\end{array}$ \\
\hline $\begin{array}{l}\text { SMSA Herfindahl Index of Public } \\
\text { School Enrollment Conc }\end{array}$ & $\begin{array}{l}-.54 \\
(.20)\end{array}$ & $\begin{array}{l}-.73 \\
(.35)\end{array}$ & $\begin{array}{l}-.51 \\
(.23)\end{array}$ \\
\hline $\begin{array}{l}\text { Share of Public School Spending from } \\
\text { State Funds }\end{array}$ & $\begin{array}{c}.42 \\
(.30)\end{array}$ & $\begin{array}{c}.37 \\
(.30)\end{array}$ & $\begin{array}{c}.47 \\
(.32)\end{array}$ \\
\hline $\begin{array}{l}\text { SMSA Land Area } \\
\text { (Hundreds of Square Miles) }\end{array}$ & $\begin{array}{l}-.009 \\
(.003)\end{array}$ & $\begin{array}{l}-.010 \\
(.005)\end{array}$ & $\begin{array}{l}-.009 \\
(.003)\end{array}$ \\
\hline $\begin{array}{l}\text { SMSA Land Area Squared } \\
\text { (Hundreds of Square Miles) }\end{array}$ & $\begin{array}{c}2.6 \mathrm{e}-7 \\
(1.0 \mathrm{e}-7)\end{array}$ & $\begin{array}{c}2.9 \mathrm{e}-7 \\
(1.6 \mathrm{e}-7)\end{array}$ & $\begin{array}{c}2.6 \mathrm{e}-7 \\
(1.1 \mathrm{e}-7)\end{array}$ \\
\hline $\begin{array}{l}\text { Total SMSA Population } \\
\text { (Millions) }\end{array}$ & $\begin{array}{l}-.02 \\
(.02)\end{array}$ & $\begin{array}{l}-.02 \\
(.02)\end{array}$ & $\begin{array}{l}-.02 \\
(.02)\end{array}$ \\
\hline SMSA Per Capita Income (Thousands) & $\begin{array}{c}.02 \\
(.05)\end{array}$ & $\begin{array}{c}.01 \\
(.06)\end{array}$ & $\begin{array}{c}.01 \\
(.06)\end{array}$ \\
\hline Parents' Highest Grade Completed & $\begin{array}{l}.23 \\
(.01)\end{array}$ & $\begin{array}{l}.23 \\
(.01)\end{array}$ & $\begin{array}{l}.23 \\
(.01)\end{array}$ \\
\hline African-American & $\begin{array}{l}.19 \\
(.06)\end{array}$ & $\begin{array}{l}.20 \\
(.06)\end{array}$ & $\begin{array}{l}.20 \\
(.06)\end{array}$ \\
\hline Hispanic & $\begin{array}{l}-.04 \\
(.08)\end{array}$ & $\begin{array}{l}-.03 \\
(.08)\end{array}$ & $\begin{array}{l}-.03 \\
(.08)\end{array}$ \\
\hline Female & $\begin{array}{l}.30 \\
(.04)\end{array}$ & $\begin{array}{l}.30 \\
(.04)\end{array}$ & $\begin{array}{l}.30 \\
(.04)\end{array}$ \\
\hline Number of Siblings & $\begin{array}{l}-.13 \\
(.01)\end{array}$ & $\begin{array}{l}-.13 \\
(.01)\end{array}$ & $\begin{array}{l}-.13 \\
(.01)\end{array}$ \\
\hline Enrollment in Student's School & $\begin{array}{c}2.5 e-4 \\
(1.1 e-4)\end{array}$ & $\begin{array}{c}2.7 e-4 \\
(1.2 e-4)\end{array}$ & $\begin{array}{c}2.5 e-4 \\
(1.1 e-4)\end{array}$ \\
\hline $\begin{array}{c}\text { Enrollment in Student's School } \\
\text { Squared }\end{array}$ & $\begin{array}{l}-6.6 e-8 \\
(3.1 e-8)\end{array}$ & $\begin{array}{l}-7.2 e-8 \\
(3.1 e-8)\end{array}$ & $\begin{array}{l}-6.7 e-8 \\
(3.1 e-8)\end{array}$ \\
\hline SMSA Per-Pupil Spending & & & $\begin{array}{l}.05 \\
(.09)\end{array}$ \\
\hline Ln(Average Teacher Salary) in SMSA & & & $\begin{array}{l}.85 \\
(.32)\end{array}$ \\
\hline Student-Teacher Ratio in SMSA & & & $\begin{array}{l}-.0008 \\
(.0018)\end{array}$ \\
\hline $\begin{array}{c}\text { U.S. Census Region Indicator } \\
\text { Variables }\end{array}$ & yes & yes & yes \\
\hline $\begin{array}{l}\text { Hausman Lagrange Mult Test of } \\
\text { Overid Restrictns Asymp Chi-Sq } \\
\text { Statistic (cum prob in paren) }\end{array}$ & & $\begin{array}{l}1.40 \\
(.25)\end{array}$ & \\
\hline
\end{tabular}


Table 6a

Effect of Market Concentration on Educational Attainment

Entries are Estimated Coefficients on Market Concentration in Public Schooling Dependent Variable is Highest Grade Completed by Public School Student by Age 24

Same Specification as Table 6, for Various Subgroups of Public School Students

\begin{tabular}{|c|c|c|}
\hline Sample & No. of Observations & $\begin{array}{l}\text { IV Estimated Coefficient } \\
\text { on SMSA Herfindahl Index of } \\
\text { Public School Enrollment Conc }\end{array}$ \\
\hline All Students & 6962 & $\begin{array}{l}-.73 \\
(.35)\end{array}$ \\
\hline $\begin{array}{l}\text { Students from large cities } \\
(>279,780 \text { pop }=\text { median })\end{array}$ & 6054 & $\begin{array}{r}-1.19 \\
(.62)\end{array}$ \\
\hline $\begin{array}{l}\text { Students from small cities } \\
(<279,780 \text { pop }=\text { median })\end{array}$ & 908 & $\begin{array}{l}-3.07 \\
(.64)\end{array}$ \\
\hline $\begin{array}{l}\text { Students whose parents have } \\
\text { education } \leq 11 \text { th grade }\end{array}$ & 2241 & $\begin{array}{c}4.57 \\
(2.65)\end{array}$ \\
\hline $\begin{array}{l}\text { Students whose parents have } \\
\text { education }=12 \text { th grade }\end{array}$ & 2511 & $\begin{array}{r}-1.30 \\
(.65)\end{array}$ \\
\hline $\begin{array}{l}\text { Students whose parents have } \\
\text { education }>12 \text { th grade }\end{array}$ & 2210 & $\begin{array}{l}-3.68 \\
(.91)\end{array}$ \\
\hline African-American Students & 1883 & $\begin{array}{c}.45 \\
(2.28)\end{array}$ \\
\hline Hispanic Students & 1240 & $\begin{array}{c}1.32 \\
(2.30)\end{array}$ \\
\hline $\begin{array}{l}\text { Non-African-American, } \\
\text { Non-Hispanic Students }\end{array}$ & 3839 & $\begin{array}{l}-.65 \\
(.31)\end{array}$ \\
\hline Female Students & 3412 & $\begin{array}{l}-.63 \\
(.65)\end{array}$ \\
\hline Male Students & 3550 & $\begin{array}{r}-1.22 \\
(.71)\end{array}$ \\
\hline
\end{tabular}

Note: Standard errors in parentheses, except as noted. Dependent variable has mean 12.3, standard deviation 2.1. Unit of observation is a public school student.

The equations estimated in this table are identical to that of Table 6, IV column. Only the sample of students over which the equations are estimated differs. See Table 6 for covariates. 
Table 7

Various Levels of Educational Attainmt \& Mkt Concentration in Public Schooling

\begin{tabular}{|c|c|c|c|c|}
\hline & \multicolumn{4}{|c|}{ Dependent Variable is an Indicator For } \\
\hline & $\begin{array}{l}\text { High School } \\
\text { Diploma by } \\
\text { Age } 19\end{array}$ & $\begin{array}{l}\text { Attended Any } \\
\text { Post-Secondary } \\
\text { School by Age } 24\end{array}$ & $\begin{array}{l}\text { Completed } 2 \\
\text { Years of College } \\
\text { by Age } 24\end{array}$ & $\begin{array}{c}\text { Graduated } \\
\text { from 4-Year } \\
\text { College by } \\
\text { Age } 24\end{array}$ \\
\hline $\begin{array}{l}\text { SMSA Herfindahl Index of } \\
\text { Public School Enrollment Conc }\end{array}$ & $\begin{array}{l}-.07 \\
(.03)\end{array}$ & $\begin{array}{l}-.09 \\
(.04)\end{array}$ & $\begin{array}{l}-.08 \\
(.04)\end{array}$ & $\begin{array}{l}-.06 \\
(.03)\end{array}$ \\
\hline $\begin{array}{l}\text { Share of Public School Spending } \\
\text { from State Funds }\end{array}$ & $\begin{array}{l}.04 \\
(.07)\end{array}$ & $\begin{array}{l}.16 \\
(.07)\end{array}$ & $\begin{array}{l}.08 \\
(.06)\end{array}$ & $\begin{array}{l}.11 \\
(.05)\end{array}$ \\
\hline $\begin{array}{c}\text { SMSA Land Area } \\
\text { (Hundreds of Square Miles) }\end{array}$ & $\begin{array}{r}-1.2 e-3 \\
(6.9 e-4)\end{array}$ & $\begin{array}{l}-6.7 e-4 \\
(7.0 e-4)\end{array}$ & $\begin{array}{l}-1.0 e-3 \\
(6.3 e-4)\end{array}$ & $\begin{array}{r}-1.3 e-3 \\
(4.9 e-4)\end{array}$ \\
\hline $\begin{array}{l}\text { SMSA Land Area Squared } \\
\text { (Hundreds of Square Miles) }\end{array}$ & $\begin{array}{c}3.3 \mathrm{e}-8 \\
(2.4 \mathrm{e}-8)\end{array}$ & $\begin{array}{c}1.3 \mathrm{e}-8 \\
(2.4 \mathrm{e}-8)\end{array}$ & $\begin{array}{c}2.0 e-8 \\
(2.2 e-8)\end{array}$ & $\begin{array}{c}3.5 \mathrm{e}-8 \\
(1.7 \mathrm{e}-8)\end{array}$ \\
\hline $\begin{array}{l}\text { Total SMSA Population } \\
\text { (Millions) }\end{array}$ & $\begin{array}{r}-3.4 \mathrm{e}-3 \\
(4.4 \mathrm{e}-3)\end{array}$ & $\begin{array}{l}-3.4 \mathrm{e}-3 \\
(4.5 \mathrm{e}-3)\end{array}$ & $\begin{array}{l}-2.9 \mathrm{e}-3 \\
(4.1 \mathrm{e}-3)\end{array}$ & $\begin{array}{l}-4.6 e-3 \\
(3.1 e-3)\end{array}$ \\
\hline $\begin{array}{c}\text { SMSA Per Capita Income } \\
\text { (Thousands) }\end{array}$ & $\begin{array}{l}.03 \\
(.01)\end{array}$ & $\begin{array}{l}.01 \\
(.01)\end{array}$ & $\begin{array}{l}.01 \\
(.01)\end{array}$ & $\begin{array}{l}.01 \\
(.01)\end{array}$ \\
\hline $\begin{array}{c}\text { Parents' Highest Grade } \\
\text { Completed }\end{array}$ & $\begin{array}{l}.028 \\
(.001)\end{array}$ & $\begin{array}{l}.044 \\
(.001)\end{array}$ & $\begin{array}{l}.039 \\
(.001)\end{array}$ & $\begin{array}{l}.026 \\
(.001)\end{array}$ \\
\hline African-American & $\begin{array}{l}.05 \\
(.01)\end{array}$ & $\begin{array}{l}.06 \\
(.01)\end{array}$ & $\begin{array}{l}.01 \\
(.01)\end{array}$ & $\begin{array}{l}-.04 \\
(.01)\end{array}$ \\
\hline Hispanic & $\begin{array}{l}-.03 \\
(.01)\end{array}$ & $\begin{array}{l}.05 \\
(.02)\end{array}$ & $\begin{array}{l}.02 \\
(.01)\end{array}$ & $\begin{array}{l}.001 \\
(.014)\end{array}$ \\
\hline Female & $\begin{array}{l}.08 \\
(.01)\end{array}$ & $\begin{array}{l}.06 \\
(.01)\end{array}$ & $\begin{array}{l}.05 \\
(.01)\end{array}$ & $\begin{array}{c}.02 \\
(.01)\end{array}$ \\
\hline Number of Siblings & $\begin{array}{l}-.022 \\
(.003)\end{array}$ & $\begin{array}{l}-.021 \\
(.003)\end{array}$ & $\begin{array}{l}-.018 \\
(.003)\end{array}$ & $\begin{array}{l}-.012 \\
(.002)\end{array}$ \\
\hline Enrollment in Student's School & $\begin{array}{c}2.1 \mathrm{e}-5 \\
(2.1 \mathrm{e}-5)\end{array}$ & $\begin{array}{c}3.1 \mathrm{e}-5 \\
(2.8 \mathrm{e}-5)\end{array}$ & $\begin{array}{c}4.5 e-5 \\
(2.6 e-5)\end{array}$ & $\begin{array}{c}3.6 e-6 \\
(2.2 e-5)\end{array}$ \\
\hline $\begin{array}{c}\text { Enrollment in Student's School } \\
\text { Squared }\end{array}$ & $\begin{array}{l}-5.9 \mathrm{e}-9 \\
(6.9 \mathrm{e}-9)\end{array}$ & $\begin{array}{l}-7.7 e-9 \\
(7.4 e-9)\end{array}$ & $\begin{array}{l}-1.5 e-8 \\
(6.9 e-9)\end{array}$ & $\begin{array}{l}-2.1 e-9 \\
(5.7 e-9)\end{array}$ \\
\hline $\begin{array}{l}\text { U.S. Census Region Indicator } \\
\text { Variables }\end{array}$ & yes & yes & yes & yes \\
\hline $\begin{array}{l}\text { Hausman Lagrange Mult Test of } \\
\text { Overid Restrictns Asymp Chi-Sq } \\
\text { Statistic (cum prob in paren) }\end{array}$ & $\begin{array}{l}2.07 \\
(.45)\end{array}$ & $\begin{array}{l}1.02 \\
(.20)\end{array}$ & $\begin{array}{l}1.08 \\
(.20)\end{array}$ & $\begin{array}{l}2.11 \\
(.45)\end{array}$ \\
\hline
\end{tabular}


Table 7a

Effect of Market Concentration on High School Graduation

Entries are Estimated Coefficients on Market Concentration in Public Schooling

Dependent Variable is Indicator for High School Diploma by Age 19

Same Specification as Table 7, for Various Subgroups of Public School Students

\begin{tabular}{|c|c|c|}
\hline Sample & No. of Observations & $\begin{array}{l}\text { IV Estimated Coefficient } \\
\text { on SMSA Herfindahl Index of } \\
\text { Public School Enrollment Conc }\end{array}$ \\
\hline All Students & 6962 & $\begin{array}{l}-.07 \\
(.03)\end{array}$ \\
\hline $\begin{array}{l}\text { Students from large cities } \\
(>279,780 \text { pop }=\text { median })\end{array}$ & 6054 & $\begin{array}{l}-.39 \\
(.29)\end{array}$ \\
\hline $\begin{array}{l}\text { Students from small cities } \\
(<279,780 \text { pop }=\text { median })\end{array}$ & 908 & $\begin{array}{l}-.20 \\
(.29)\end{array}$ \\
\hline $\begin{array}{l}\text { Students whose parents have } \\
\text { education } \leq 11 \text { th grade }\end{array}$ & 2241 & $\begin{array}{l}-.65 \\
(.35)\end{array}$ \\
\hline $\begin{array}{l}\text { Students whose parents have } \\
\text { education }=12 \text { th grade }\end{array}$ & 2511 & $\begin{array}{l}-.58 \\
(.14)\end{array}$ \\
\hline $\begin{array}{l}\text { Students whose parents have } \\
\text { education }>12 \text { th grade }\end{array}$ & 2210 & $\begin{array}{l}-.28 \\
(.16)\end{array}$ \\
\hline African-American Students & 1883 & $\begin{array}{l}-.72 \\
(.27)\end{array}$ \\
\hline Hispanic Students & 1240 & $\begin{array}{l}-.92 \\
(.26)\end{array}$ \\
\hline $\begin{array}{l}\text { Non-African-American, } \\
\text { Non-Hispanic Students }\end{array}$ & 3839 & $\begin{array}{l}-.69 \\
(.10)\end{array}$ \\
\hline Female Students & 3412 & $\begin{array}{l}-.38 \\
(.16)\end{array}$ \\
\hline Male Students & 3550 & $\begin{array}{l}-.74 \\
(.20)\end{array}$ \\
\hline
\end{tabular}

Note: Standard errors in parentheses, except as noted. Dependent variable has mean .70, standard deviation .45 . Unit of observation is a public school student.

The equations estimated in this table are identical to that of Table 7, high school diploma. Only the sample of students over which the equations are estimated differs. See Table 7 for covariates. 
Table $7 \mathrm{~b}$

Effect of Market Concentration on Graduation from a 4-Year College

Entries are Estimated Coefficients on Market Concentration in Public Schooling Dependent Variable is Indicator for Graduated from 4-Year College by Age 24 Same Specification as Table 7, for Various Subgroups of Public School Students

\begin{tabular}{|c|c|c|}
\hline Sample & No. of Observations & $\begin{array}{l}\text { IV Estimated Coefficient } \\
\text { on SMSA Herfindahl Index of } \\
\text { Public School Enrollment Conc }\end{array}$ \\
\hline All Students & 6962 & $\begin{array}{l}-.06 \\
(.03)\end{array}$ \\
\hline $\begin{array}{l}\text { Students from large cities } \\
(>279,780 \text { pop }=\text { median })\end{array}$ & 6054 & $\begin{array}{l}-.29 \\
(.11)\end{array}$ \\
\hline $\begin{array}{l}\text { Students from small cities } \\
(<279,780 \text { pop }=\text { median })\end{array}$ & 908 & $\begin{array}{l}-.69 \\
(.9)\end{array}$ \\
\hline $\begin{array}{l}\text { Students whose parents have } \\
\text { education } \leq 11 \text { th grade }\end{array}$ & 2241 & $\begin{array}{l}-.15 \\
(.12)\end{array}$ \\
\hline $\begin{array}{l}\text { Students whose parents have } \\
\text { education }=12 \text { th grade }\end{array}$ & 2511 & $\begin{array}{l}-.06 \\
(.8)\end{array}$ \\
\hline $\begin{array}{l}\text { Students whose parents have } \\
\text { education }>12^{\text {th }} \text { grade }\end{array}$ & 2210 & $\begin{array}{l}-.51 \\
(.17)\end{array}$ \\
\hline African-American Students & 1883 & $\begin{array}{l}-.03 \\
(.16)\end{array}$ \\
\hline Hispanic Students & 1240 & $\begin{array}{l}.88 \\
(.12)\end{array}$ \\
\hline $\begin{array}{l}\text { Non-African-American, } \\
\text { Non-Hispanic Students }\end{array}$ & 3839 & $\begin{array}{l}-.11 \\
(.7)\end{array}$ \\
\hline Female Students & 3412 & $\begin{array}{l}-.07 \\
(.11)\end{array}$ \\
\hline Male Students & 3550 & $\begin{array}{l}-.29 \\
(.11)\end{array}$ \\
\hline
\end{tabular}

Note: Standard errors in parentheses, except as noted. Dependent variable has mean .13, standard deviation . 33 . Unit of observation is a public school student.

The equations estimated in this table are identical to that of Table 7, graduated from 4-yr college column. Only the sample of students over which the equations are estimated differs. See Table 7 for covariates. 
Table 8

Wages and Market Concentration in Public Schooling

Dependent Variable: Ln(wage) of Public Schl Student Most Recent Job (\$1990)

(mean 2.12, standard deviation .47)

\begin{tabular}{|c|c|c|c|}
\hline & FGLS & $\begin{array}{c}\text { IV } \\
\text { (adj std errs) }\end{array}$ & $\begin{array}{c}\text { FGLS } \\
\text { Controls: School } \\
\text { Characteristics }\end{array}$ \\
\hline $\begin{array}{l}\text { SMSA Herfindahl Index of Public } \\
\text { School Enrollment Conc }\end{array}$ & $\begin{array}{l}-.14 \\
(.05)\end{array}$ & $\begin{array}{l}-.13 \\
(.08)\end{array}$ & $\begin{array}{l}-.15 \\
(.06)\end{array}$ \\
\hline $\begin{array}{c}\text { Share of Public School Spending from } \\
\text { State Funds }\end{array}$ & $\begin{array}{l}.08 \\
(.08)\end{array}$ & $\begin{array}{l}.08 \\
(.08)\end{array}$ & $\begin{array}{l}.16 \\
(.09)\end{array}$ \\
\hline $\begin{array}{c}\text { SMSA Land Area } \\
\text { (Hundreds of Square Miles) }\end{array}$ & $\begin{array}{l}-.002 \\
(.001)\end{array}$ & $\begin{array}{r}-9.2 e-4 \\
(1.6 e-3)\end{array}$ & $\begin{array}{l}-.002 \\
(.001)\end{array}$ \\
\hline $\begin{array}{l}\text { SMSA Land Area Squared } \\
\text { (Hundreds of Square Miles) }\end{array}$ & $\begin{array}{c}6.7 \mathrm{e}-8 \\
(2.9 \mathrm{e}-8)\end{array}$ & $\begin{array}{c}3.1 \mathrm{e}-8 \\
(5.1 \mathrm{e}-8)\end{array}$ & $\begin{array}{c}7.8 \mathrm{e}-8 \\
(3.0 \mathrm{e}-8)\end{array}$ \\
\hline $\begin{array}{l}\text { Total SMSA Population } \\
\text { (Millions) }\end{array}$ & $\begin{array}{l}.011 \\
(.005)\end{array}$ & $\begin{array}{l}.008 \\
(.006)\end{array}$ & $\begin{array}{l}.008 \\
(.005)\end{array}$ \\
\hline Ln(SMSA Per Capita Income) & $\begin{array}{l}.06 \\
(.04)\end{array}$ & $\begin{array}{l}.06 \\
(.04)\end{array}$ & $\begin{array}{l}.10 \\
(.04)\end{array}$ \\
\hline Parents' Highest Grade Completed & $\begin{array}{l}.026 \\
(.002)\end{array}$ & $\begin{array}{l}.026 \\
(.002)\end{array}$ & $\begin{array}{l}.026 \\
(.002)\end{array}$ \\
\hline African-American & $\begin{array}{l}-.15 \\
(.02)\end{array}$ & $\begin{array}{l}-.15 \\
(.02)\end{array}$ & $\begin{array}{l}-.15 \\
(.02)\end{array}$ \\
\hline Hispanic & $\begin{array}{l}-.03 \\
(.02)\end{array}$ & $\begin{array}{l}-.03 \\
(.02)\end{array}$ & $\begin{array}{l}-.03 \\
(.02)\end{array}$ \\
\hline Female & $\begin{array}{l}-.16 \\
(.01)\end{array}$ & $\begin{array}{l}-.16 \\
(.01)\end{array}$ & $\begin{array}{l}-.16 \\
(.01)\end{array}$ \\
\hline Number of Siblings & $\begin{array}{l}-.02 \\
(.01)\end{array}$ & $\begin{array}{l}-.02 \\
(.01)\end{array}$ & $\begin{array}{l}-.02 \\
(.01)\end{array}$ \\
\hline Enrollment in Student's School & $\begin{array}{c}3.1 \mathrm{e}-5 \\
(3.1 \mathrm{e}-5)\end{array}$ & $\begin{array}{l}4.6 e-5 \\
(3.2 e-5)\end{array}$ & $\begin{array}{c}3.3 e-5 \\
(3.1 e-5)\end{array}$ \\
\hline $\begin{array}{c}\text { Enrollment in Student's School } \\
\text { Squared }\end{array}$ & $\begin{array}{l}-3.2 \mathrm{e}-9 \\
(8.1 \mathrm{e}-9)\end{array}$ & $\begin{array}{r}-6.7 e-9 \\
(8.4 e-9)\end{array}$ & $\begin{array}{l}-3.2 \mathrm{e}-9 \\
(8.1 \mathrm{e}-9)\end{array}$ \\
\hline SMSA Per-Pupil Spending & & & $\begin{array}{r}-.02 \\
(.02)\end{array}$ \\
\hline Ln(Average Teacher Salary) in SMSA & & & $\begin{array}{l}.24 \\
(.08)\end{array}$ \\
\hline Student-Teacher Ratio in SMSA & & & $\begin{array}{l}-.0005 \\
(.0005)\end{array}$ \\
\hline $\begin{array}{l}\text { U.S. Census Region Indicator } \\
\text { Variables }\end{array}$ & yes & yes & yes \\
\hline $\begin{array}{l}\text { Hausman Lagrange Mult Test of } \\
\text { Overid Restrictns Asymp Chi-Sq } \\
\text { Statistic (cum prob in paren) }\end{array}$ & & $\begin{array}{l}3.12 \\
(.60)\end{array}$ & \\
\hline
\end{tabular}


Table 8a

Effect of Market Concentration on Wages

Entries are Estimated Coefficients on Market Concentration in Public Schooling Dependent Variable is Ln(Wage) of Public School Student in Most Recent Job (\$1990)

Same Specification as Table 8, for Various Subgroups of Public School Students

\begin{tabular}{|c|c|c|}
\hline Sample & No. of Observations & $\begin{array}{l}\text { IV Estimated Coefficient } \\
\text { on SMSA Herfindahl Index of } \\
\text { Public School Enrollment Conc }\end{array}$ \\
\hline All Students & 5011 & $\begin{array}{l}-.13 \\
(.08)\end{array}$ \\
\hline $\begin{array}{l}\text { Students from large cities } \\
(>279,780 \text { pop }=\text { median })\end{array}$ & 4358 & $\begin{array}{l}-.09 \\
(.16)\end{array}$ \\
\hline $\begin{array}{l}\text { Students from small cities } \\
(<279,780 \text { pop }=\text { median })\end{array}$ & 653 & $\begin{array}{l}-.67 \\
(.17)\end{array}$ \\
\hline $\begin{array}{l}\text { Students whose parents have } \\
\text { education } \leq 11 \text { th grade }\end{array}$ & 1557 & $\begin{array}{l}-.11 \\
(.42)\end{array}$ \\
\hline $\begin{array}{l}\text { Students whose parents have } \\
\text { education }=12 \text { th grade }\end{array}$ & 1852 & $\begin{array}{l}-.24 \\
(.11)\end{array}$ \\
\hline $\begin{array}{l}\text { Students whose parents have } \\
\text { education }>12^{\text {th }} \text { grade }\end{array}$ & 1602 & $\begin{array}{l}-.32 \\
(.22)\end{array}$ \\
\hline African-American Students & 1355 & $\begin{array}{l}-.81 \\
(.38)\end{array}$ \\
\hline Hispanic Students & 954 & $\begin{array}{l}1.04 \\
(.69)\end{array}$ \\
\hline $\begin{array}{l}\text { Non-African-American, } \\
\text { Non-Hispanic Students }\end{array}$ & 2702 & $\begin{array}{l}-.24 \\
(.28)\end{array}$ \\
\hline Female Students & 2388 & $\begin{array}{l}-.35 \\
(.17)\end{array}$ \\
\hline Male Students & 2623 & $\begin{array}{l}-.47 \\
(.22)\end{array}$ \\
\hline
\end{tabular}

Note: Standard errors in parentheses, except as noted. Dependent variable has mean 2.12, standard deviation .47. Unit of observation is a public school student.

The equations estimated in this table are identical to that of Table 8, IV column. Only the sample of students over which the equations are estimated differs. See Table 8 for covariates. 
Table 9

AFQT Scores and Market Concentration in Public Schooling

Dependent Variable: AFQT Percentile Score of Public School Student (mean 41.0, standard deviation 28.5)

\begin{tabular}{|c|c|c|c|}
\hline & FGLS & $\begin{array}{c}\text { IV } \\
\text { (adj std errs) }\end{array}$ & $\begin{array}{c}\text { FGLS } \\
\text { Controls: School Characteristics }\end{array}$ \\
\hline $\begin{array}{l}\text { SMSA Herfindahl Index of Public } \\
\text { School Enrollment Conc }\end{array}$ & $\begin{array}{l}-2.3 \\
(2.5)\end{array}$ & $\begin{array}{l}-3.0 \\
(5.2)\end{array}$ & $\begin{array}{l}-2.4 \\
(2.6)\end{array}$ \\
\hline $\begin{array}{l}\text { Share of Public School Spending from } \\
\text { State Funds }\end{array}$ & $\begin{array}{l}-1.1 \\
(3.8)\end{array}$ & $\begin{array}{l}-1.2 \\
(3.8)\end{array}$ & $\begin{array}{l}-1.3 \\
(4.0)\end{array}$ \\
\hline $\begin{array}{c}\text { SMSA Land Area } \\
\text { (Hundreds of Square Miles) }\end{array}$ & $\begin{array}{l}-.04 \\
(.03)\end{array}$ & $\begin{array}{l}-.05 \\
(.06)\end{array}$ & $\begin{array}{l}-.06 \\
(.04)\end{array}$ \\
\hline $\begin{array}{l}\text { SMSA Land Area Squared } \\
\text { (Hundreds of Square Miles) }\end{array}$ & $\begin{array}{c}7.8 \mathrm{e}-7 \\
(1.3 \mathrm{e}-6)\end{array}$ & $\begin{array}{c}1.0 e-6 \\
(1.9 e-6)\end{array}$ & $\begin{array}{c}1.2 \mathrm{e}-6 \\
(1.3 \mathrm{e}-6)\end{array}$ \\
\hline $\begin{array}{c}\text { Total SMSA Population } \\
\text { (Millions) }\end{array}$ & $\begin{array}{l}-.07 \\
(.24)\end{array}$ & $\begin{array}{l}-.13 \\
(.26)\end{array}$ & $\begin{array}{l}-.12 \\
(.26)\end{array}$ \\
\hline SMSA Per Capita Income (Thousands) & $\begin{array}{l}.54 \\
(.67)\end{array}$ & $\begin{array}{l}.47 \\
(.76)\end{array}$ & $\begin{array}{l}.63 \\
(.74)\end{array}$ \\
\hline Parents' Highest Grade Completed & $\begin{array}{l}2.8 \\
(.1)\end{array}$ & $\begin{array}{l}2.8 \\
(.1)\end{array}$ & $\begin{array}{l}2.8 \\
(.1)\end{array}$ \\
\hline African-American & $\begin{array}{l}-18.7 \\
(.8)\end{array}$ & $\begin{array}{l}-18.8 \\
(.8)\end{array}$ & $\begin{array}{c}-18.7 \\
(.8)\end{array}$ \\
\hline Hispanic & $\begin{array}{r}-10.6 \\
(1.0)\end{array}$ & $\begin{array}{l}-10.5 \\
(1.0)\end{array}$ & $\begin{array}{r}-10.5 \\
(1.0)\end{array}$ \\
\hline Female & $\begin{array}{l}-.8 \\
(.5)\end{array}$ & $\begin{array}{l}-.9 \\
(.5)\end{array}$ & $\begin{array}{l}-.8 \\
(.5)\end{array}$ \\
\hline Number of Siblings & $\begin{array}{l}-1.2 \\
(.2)\end{array}$ & $\begin{array}{l}-1.2 \\
(.2)\end{array}$ & $\begin{array}{r}-1.2 \\
(.2)\end{array}$ \\
\hline SMSA Per-Pupil Spending & & & $\begin{array}{c}-.26 \\
(1.10)\end{array}$ \\
\hline Ln(Average Teacher Salary) in SMSA & & & $\begin{array}{c}3.4 \\
(3.9)\end{array}$ \\
\hline Student-Teacher Ratio in SMSA & & & $\begin{array}{c}-.02 \\
(.02)\end{array}$ \\
\hline U.S. Census Region Indicator Vars & yes & yes & yes \\
\hline Age at Test-Taking Indicator Variables & yes & yes & yes \\
\hline $\begin{array}{l}\text { Hausman Lagrange Mult Test of } \\
\text { Overid Restrictns Asymp Chi-Sq } \\
\text { Statistic (cum prob in paren) }\end{array}$ & & $\begin{array}{l}3.77 \\
(.70)\end{array}$ & \\
\hline
\end{tabular}

Note: Standard errors in parentheses, except as noted. 6962 observations (public school students). See note preceeding Table 6. 
Table 10

Various Levels of AFQT Achievement \& Mkt Concentration in Public Schooling

\begin{tabular}{|c|c|c|c|c|}
\hline & \multicolumn{4}{|c|}{ Dependent Variable is an Indicator For } \\
\hline & $\begin{array}{l}\text { Scored in } \\
\text { Lowest 10th } \\
\text { Percentile }\end{array}$ & $\begin{array}{l}\text { Scored in } \\
\text { Lowest } 25 \text { th } \\
\text { Percentile }\end{array}$ & $\begin{array}{l}\text { Scored in } \\
\text { Highest 25th } \\
\text { Percentile }\end{array}$ & $\begin{array}{l}\text { Scored in } \\
\text { Highest 10th } \\
\text { Percentile }\end{array}$ \\
\hline $\begin{array}{l}\text { SMSA Herfindahl Index of } \\
\text { Public School Enrollment Conc }\end{array}$ & $\begin{array}{l}.01 \\
(.03)\end{array}$ & $\begin{array}{l}.07 \\
(.04)\end{array}$ & $\begin{array}{l}-.05 \\
(.02)\end{array}$ & $\begin{array}{l}-.01 \\
(.01)\end{array}$ \\
\hline $\begin{array}{l}\text { Share of Public School Spending } \\
\text { from State Funds }\end{array}$ & $\begin{array}{l}.12 \\
(.05)\end{array}$ & $\begin{array}{c}.01 \\
(.07)\end{array}$ & $\begin{array}{l}.02 \\
(.05)\end{array}$ & $\begin{array}{l}-.01 \\
(.03)\end{array}$ \\
\hline $\begin{array}{c}\text { SMSA Land Area } \\
\text { (Hundreds of Square Miles) }\end{array}$ & $\begin{array}{l}-1.7 e-4 \\
(5.6 e-4)\end{array}$ & $\begin{array}{l}-1.5 e-6 \\
(6.8 e-4)\end{array}$ & $\begin{array}{l}-7.3 e-4 \\
(5.6 e-4)\end{array}$ & $\begin{array}{l}-4.5 e-4 \\
(3.8 e-4)\end{array}$ \\
\hline $\begin{array}{l}\text { SMSA Land Area Squared } \\
\text { (Hundreds of Square Miles) }\end{array}$ & $\begin{array}{c}8.3 e-9 \\
(1.9 e-8)\end{array}$ & $\begin{array}{l}5.4 \mathrm{e}-9 \\
(2.3 \mathrm{e}-8)\end{array}$ & $\begin{array}{c}1.7 \mathrm{e}-8 \\
(1.9 \mathrm{e}-8)\end{array}$ & $\begin{array}{c}1.3 e-8 \\
(1.3 e-8)\end{array}$ \\
\hline $\begin{array}{l}\text { Total SMSA Population } \\
\text { (Millions) }\end{array}$ & $\begin{array}{c}5.8 \mathrm{e}-3 \\
(3.6 \mathrm{e}-3)\end{array}$ & $\begin{array}{c}2.3 e-3 \\
(4.4 \mathrm{e}-3)\end{array}$ & $\begin{array}{l}-3.2 e-4 \\
(3.6 e-3)\end{array}$ & $\begin{array}{l}-7.9 e-4 \\
(2.4 e-3)\end{array}$ \\
\hline $\begin{array}{l}\text { SMSA Per Capita Income } \\
\text { (Thousands) }\end{array}$ & $\begin{array}{l}-.01 \\
(.01)\end{array}$ & $\begin{array}{l}-.01 \\
(.01)\end{array}$ & $\begin{array}{l}.01 \\
(.01)\end{array}$ & $\begin{array}{l}.01 \\
(.01)\end{array}$ \\
\hline $\begin{array}{c}\text { Parents' Highest Grade } \\
\text { Completed }\end{array}$ & $\begin{array}{l}-.021 \\
(.001)\end{array}$ & $\begin{array}{l}-.036 \\
(.001)\end{array}$ & $\begin{array}{l}.029 \\
(.001)\end{array}$ & $\begin{array}{l}.014 \\
(.001)\end{array}$ \\
\hline African-American & $\begin{array}{l}.16 \\
(.01)\end{array}$ & $\begin{array}{l}.28 \\
(.01)\end{array}$ & $\begin{array}{l}-.13 \\
(.01)\end{array}$ & $\begin{array}{l}-.05 \\
(.01)\end{array}$ \\
\hline Hispanic & $\begin{array}{l}.09 \\
(.01)\end{array}$ & $\begin{array}{l}.18 \\
(.01)\end{array}$ & $\begin{array}{l}-.04 \\
(.01)\end{array}$ & $\begin{array}{l}-.01 \\
(.01)\end{array}$ \\
\hline Female & $\begin{array}{l}-.03 \\
(.01)\end{array}$ & $\begin{array}{l}-.01 \\
(.01)\end{array}$ & $\begin{array}{l}-.03 \\
(.01)\end{array}$ & $\begin{array}{l}-.03 \\
(.01)\end{array}$ \\
\hline Number of Siblings & $\begin{array}{l}.021 \\
(.002)\end{array}$ & $\begin{array}{l}.022 \\
(.003)\end{array}$ & $\begin{array}{l}-.006 \\
(.002)\end{array}$ & $\begin{array}{l}-.002 \\
(.002)\end{array}$ \\
\hline $\begin{array}{c}\text { U.S. Census Region Indicator } \\
\text { Variables }\end{array}$ & yes & yes & yes & yes \\
\hline $\begin{array}{l}\text { Hausman Lagrange Mult Test of } \\
\text { Overid Restrictns Asymp Chi-Sq } \\
\text { Statistic (cum prob in paren) }\end{array}$ & $\begin{array}{l}2.38 \\
(.50)\end{array}$ & $\begin{array}{l}2.02 \\
(.45)\end{array}$ & $\begin{array}{l}2.18 \\
(.50)\end{array}$ & $\begin{array}{l}3.76 \\
(.70)\end{array}$ \\
\hline
\end{tabular}

Note: Standard errors in parentheses, except as noted. 6962 observations (public school students). See note preceeding Table 6.

The indicator for AFQT score in the lowest 10th percentile bas mean .17 and standard deviation . 37. The indicator for AFQT score in the lowest 25 th percentile has mean .38 and standard deviation .48. The indicator for AFQT score in the highest 25 th percentile has mean .16 and standard deviation .37. The indicator for AFQT score in the highest 10 th percentile has mean .06 and standard deviation .24 . 
Table 11

Private School Enrollment and Market Concentration in Public Schooling

Dependent Variable: Share of SMSA Enrollment in Private Schools

(mean .10, standard deviation .07)

\begin{tabular}{|c|c|c|}
\hline & OLS & IV \\
\hline $\begin{array}{l}\text { SMSA Herfindahl Index of Public } \\
\text { School Enrollment Conc }\end{array}$ & $\begin{array}{l}.04 \\
(.01)\end{array}$ & $\begin{array}{l}.04 \\
(.02)\end{array}$ \\
\hline $\begin{array}{l}\text { Share of Public School Spending } \\
\text { from State Funds }\end{array}$ & $\begin{array}{l}-.02 \\
(.02)\end{array}$ & $\begin{array}{l}-.02 \\
(.02)\end{array}$ \\
\hline $\begin{array}{c}\text { SMSA Land Area } \\
\text { (Hundreds of Square Miles) }\end{array}$ & $\begin{array}{l}-1.2 e-4 \\
(2.6 e-4)\end{array}$ & $\begin{array}{l}-1.9 e-4 \\
(3.7 e-4)\end{array}$ \\
\hline $\begin{array}{l}\text { SMSA Land Area Squared } \\
\text { (Hundreds of Square Miles) }\end{array}$ & $\begin{array}{c}1.2 \mathrm{e}-8 \\
(1.0 \mathrm{e}-8)\end{array}$ & $\begin{array}{c}1.4 \mathrm{e}-8 \\
(1.3 \mathrm{e}-8)\end{array}$ \\
\hline Total SMSA Population (Millions) & $\begin{array}{l}-1.1 \mathrm{e}-3 \\
(2.8 \mathrm{e}-3)\end{array}$ & $\begin{array}{l}-1.4 \mathrm{e}-3 \\
(3.0 \mathrm{e}-3)\end{array}$ \\
\hline Share of SMSA Population Urban & $\begin{array}{l}.01 \\
(.03)\end{array}$ & $\begin{array}{l}.01 \\
(.03)\end{array}$ \\
\hline $\begin{array}{l}\text { SMSA Per Capita Income } \\
\text { (Thousands) }\end{array}$ & $\begin{array}{l}.005 \\
(.002)\end{array}$ & $\begin{array}{l}.005 \\
(.002)\end{array}$ \\
\hline $\begin{array}{l}\text { Share of SMSA Households with } \\
\text { Income Below Poverty Level }\end{array}$ & $\begin{array}{l}.17 \\
(.26)\end{array}$ & $\begin{array}{l}.15 \\
(.27)\end{array}$ \\
\hline $\begin{array}{l}\text { Share of SMSA Households } \\
\text { Headed by Females }\end{array}$ & $\begin{array}{c}.46 \\
(.30)\end{array}$ & $\begin{array}{l}.37 \\
(.33)\end{array}$ \\
\hline $\begin{array}{l}\text { Share of SMSA Adult Population } \\
\text { with } 16+\text { Years of Education }\end{array}$ & $\begin{array}{l}.03 \\
(.10)\end{array}$ & $\begin{array}{l}.02 \\
(.10)\end{array}$ \\
\hline $\begin{array}{l}\text { Gini Coefficient on SMSA } \\
\text { Households Incomes }\end{array}$ & $\begin{array}{l}.34 \\
(.53)\end{array}$ & $\begin{array}{l}.37 \\
(.55)\end{array}$ \\
\hline $\begin{array}{l}\text { Share of SMSA Population who } \\
\text { are Catholic Adherents }\end{array}$ & $\begin{array}{l}.23 \\
(.03)\end{array}$ & $\begin{array}{l}.23 \\
(.03)\end{array}$ \\
\hline $\begin{array}{c}\text { U.S. Census Region Indicator } \\
\text { Vars }\end{array}$ & yes & yes \\
\hline $\begin{array}{l}\text { Hausman Lagrange Mult Test of } \\
\text { Overid Restrictns Asymp Chi-Sq } \\
\text { Statistic (cum prob in paren) }\end{array}$ & & $\begin{array}{l}3.51 \\
(.65)\end{array}$ \\
\hline
\end{tabular}

Note: Standard errors in parentheses, except as noted. 264 observations (SMSAs).

Covariates not shown in table: share of SMSA households with $\$ 10,000-20,000$ income, share of SMSA households with $\$ 20,000-30,000$ income,..., share of SMSA households with $\$ 50,000$ or more income, share of SMSA households who receive transfer payments, share of SMSA population who are African-American, share of SMSA population who are Hispanic, share of SMSA population who are Asian, share of SMSA population who are Native American, share of SMSA adult population who have at least 12 years of education, Herfindahl index of SMSA racial homogeneity, shares of SMSA population who are Lutheran, Baptist, Episcopalian, Friends, Jewish, Methodist, and Presbyterian adherents. 
Table 12

No Sample Selection -- Both Public and Private School Students Included Effect of Public Schl Enrollmt Conc on Educational Attainmt, Wages, Test Scores

\begin{tabular}{|c|c|c|c|}
\hline & \multicolumn{3}{|c|}{ Dependent Variable } \\
\hline & $\begin{array}{c}\text { Highest Grade } \\
\text { Completed by age } 24\end{array}$ & $\begin{array}{l}\text { Ln(Hourly Wage) } \\
\text { on Most Recent Job }\end{array}$ & $\begin{array}{l}\text { AFQT Score in } \\
\text { Highest 25th Percentile }\end{array}$ \\
\hline $\begin{array}{l}\text { SMSA Herfindahl Index of } \\
\text { Public School Enrollment Conc }\end{array}$ & $\begin{array}{l}-.57 \\
(.20)\end{array}$ & $\begin{array}{l}-.16 \\
(.05)\end{array}$ & $\begin{array}{l}-.05 \\
(.02)\end{array}$ \\
\hline $\begin{array}{l}\text { Share of Public School Spending } \\
\text { from State Funds }\end{array}$ & $\begin{array}{l}.33 \\
(.30)\end{array}$ & $\begin{array}{l}.04 \\
(.08)\end{array}$ & $\begin{array}{l}.02 \\
(.05)\end{array}$ \\
\hline $\begin{array}{c}\text { SMSA Land Area } \\
\text { (Hundreds of Square Miles) }\end{array}$ & $\begin{array}{l}-.008 \\
(.003)\end{array}$ & $\begin{array}{l}-.002 \\
(.001)\end{array}$ & $\begin{array}{l}-6.6 e-4 \\
(5.5 e-4)\end{array}$ \\
\hline $\begin{array}{l}\text { SMSA Land Area Squared } \\
\text { (Hundreds of Square Miles) }\end{array}$ & $\begin{array}{c}2.1 \mathrm{e}-7 \\
(1.0 \mathrm{e}-7)\end{array}$ & $\begin{array}{l}6.5 e-8 \\
(2.8 e-8)\end{array}$ & $\begin{array}{c}1.4 \mathrm{e}-8 \\
(1.9 \mathrm{e}-8)\end{array}$ \\
\hline $\begin{array}{c}\text { Total SMSA Population } \\
\text { (Millions) }\end{array}$ & $\begin{array}{c}. .04 \\
(.01)\end{array}$ & $\begin{array}{l}.006 \\
(.005)\end{array}$ & $\begin{array}{l}-2.9 \mathrm{e}-3 \\
(3.5 \mathrm{e}-3)\end{array}$ \\
\hline $\begin{array}{l}\text { SMSA Per Capita Income } \\
\text { (Thousands) }\end{array}$ & $\begin{array}{l}.10 \\
(.05)\end{array}$ & $\begin{array}{l}.09 \\
(.04)\end{array}$ & $\begin{array}{l}.02 \\
(.01)\end{array}$ \\
\hline $\begin{array}{l}\text { Parents' Highest Grade } \\
\text { Completed }\end{array}$ & $\begin{array}{l}.24 \\
(.01)\end{array}$ & $\begin{array}{l}.027 \\
(.002)\end{array}$ & $\begin{array}{l}.029 \\
(.001)\end{array}$ \\
\hline African-American & $\begin{array}{l}.19 \\
(.06)\end{array}$ & $\begin{array}{l}-.14 \\
(.02)\end{array}$ & $\begin{array}{l}-.14 \\
(.01)\end{array}$ \\
\hline Hispanic & $\begin{array}{l}-.06 \\
(.08)\end{array}$ & $\begin{array}{l}-.03 \\
(.02)\end{array}$ & $\begin{array}{l}-.05 \\
(.01)\end{array}$ \\
\hline Female & $\begin{array}{l}.29 \\
(.04)\end{array}$ & $\begin{array}{l}-.16 \\
(.01)\end{array}$ & $\begin{array}{l}-.03 \\
(.01)\end{array}$ \\
\hline Number of Siblings & $\begin{array}{l}-.14 \\
(.01)\end{array}$ & $\begin{array}{l}-.02 \\
(.01)\end{array}$ & $\begin{array}{l}-.007 \\
(.002)\end{array}$ \\
\hline $\begin{array}{c}\text { U.S. Census Region Indicator } \\
\text { Variables }\end{array}$ & yes & yes & yes \\
\hline
\end{tabular}

Note: Std. errors in parentheses, except as noted. 7525 observations (public and private school students).

Covariates not shown in tables: share of SMSA population classified as urban, share of SMSA households with income below poverty level, share of SMSA households with $\$ 10,000-20,000$ income, ..., share of SMSA households with $\$ 50,000$ or more income, share of SMSA households who receive transfer payments, share of SMSA households headed by females, share of SMSA population who are African-American, share of SMSA population who are Hispanic, share of SMSA population who are Asian, share of SMSA population who are Native American, share of SMSA adult population who have at least 12 years of education, share of SMSA adult population who have at least 16 years of education, Gini coefficient on SMSA household incomes, Herfindahl index of SMSA racial homogeneity, shares of SMSA population who are Catholic, Lutheran, Baptist, Episcopalian, Friends, Jewish, Methodist, and Presbyterian adherents; indicator variables for religious denomination in which student was raised; birth order. 
Table 13

Private School Enrollmt and the Effect of Public School Enrollmt Concentration on Per-Pupil Spending, Teacher Salaries, and Student-Teacher Ratio

\begin{tabular}{|c|c|c|c|}
\hline & \multicolumn{3}{|c|}{ Dependent Variable } \\
\hline & $\begin{array}{l}\text { Per-Pupil Spending } \\
\text { in SMSA }\end{array}$ & $\begin{array}{l}\text { Ln(Avg Teacher } \\
\text { Salary in SMSA) }\end{array}$ & $\begin{array}{l}\text { Student-Teacher } \\
\text { Ratio in SMSA }\end{array}$ \\
\hline $\begin{array}{l}\text { SMSA Herfindahl Index of } \\
\text { Public School Enrollment Conc }\end{array}$ & $\begin{array}{c}478 \\
(125)\end{array}$ & $\begin{array}{l}.04 \\
(.01)\end{array}$ & $\begin{array}{l}-1.5 \\
(.8)\end{array}$ \\
\hline $\begin{array}{c}\text { Share of SMSA Enrollment in } \\
\text { Private Schools }\end{array}$ & $\begin{array}{c}837 \\
(600)\end{array}$ & $\begin{array}{l}.11 \\
(.08)\end{array}$ & $\begin{array}{l}-11.7 \\
(5.6)\end{array}$ \\
\hline $\begin{array}{l}\text { Share of Public School Spending } \\
\text { from State Funds }\end{array}$ & $\begin{array}{c}130 \\
(208)\end{array}$ & $\begin{array}{l}-.10 \\
(.02)\end{array}$ & $\begin{array}{l}.6 \\
(1.9)\end{array}$ \\
\hline $\begin{array}{c}\text { SMSA Land Area } \\
\text { (Hundreds of Square Miles) }\end{array}$ & $\begin{array}{c}5.3 \\
(2.4)\end{array}$ & $\begin{array}{c}1.7 e-4 \\
(2.2 e-4)\end{array}$ & $\begin{array}{l}-.02 \\
(.02)\end{array}$ \\
\hline $\begin{array}{l}\text { SMSA Land Area Squared } \\
\text { (Hundreds of Square Miles) }\end{array}$ & $\begin{array}{l}-1.7 e-4 \\
(9.7 e-5)\end{array}$ & $\begin{array}{r}-7.6 e-9 \\
(7.4 e-9)\end{array}$ & $\begin{array}{c}7.6 e-7 \\
(8.1 e-6)\end{array}$ \\
\hline $\begin{array}{l}\text { Total SMSA Population } \\
\text { (Millions) }\end{array}$ & $\begin{array}{c}-3.6 \\
(26.0)\end{array}$ & $\begin{array}{c}4.6 \mathrm{e}-3 \\
(1.3 \mathrm{e}-3)\end{array}$ & $\begin{array}{l}.2 \\
(.2)\end{array}$ \\
\hline $\begin{array}{l}\text { Share of SMSA Population } \\
\text { Classified as Urban }\end{array}$ & $\begin{array}{c}-11 \\
(295)\end{array}$ & $\begin{array}{l}.03 \\
(.03)\end{array}$ & $\begin{array}{c}-.8 \\
(2.5)\end{array}$ \\
\hline $\begin{array}{l}\text { SMSA Per Capita Income } \\
\text { (Thousands) }\end{array}$ & $\begin{array}{c}38 \\
(35)\end{array}$ & $\begin{array}{l}.03 \\
(.01)\end{array}$ & $\begin{array}{l}-.3 \\
(.3)\end{array}$ \\
\hline $\begin{array}{l}\text { Share of SMSA Households with } \\
\text { Income below Poverty Level }\end{array}$ & $\begin{array}{c}4931 \\
(2388)\end{array}$ & $\begin{array}{l}-.06 \\
(.25)\end{array}$ & $\begin{array}{l}-47.3 \\
(19.9)\end{array}$ \\
\hline $\begin{array}{c}\text { Share of SMSA Households } \\
\text { Headed by Females }\end{array}$ & $\begin{array}{l}-6464 \\
(2775)\end{array}$ & $\begin{array}{l}-.15 \\
(.34)\end{array}$ & $\begin{array}{c}30.2 \\
(24.2)\end{array}$ \\
\hline $\begin{array}{l}\text { Share of SMSA Adult Population } \\
\text { with } 16+\text { Years of Education }\end{array}$ & $\begin{array}{l}1367 \\
(910)\end{array}$ & $\begin{array}{l}.07 \\
(.11)\end{array}$ & $\begin{array}{c}1.6 \\
(8.0)\end{array}$ \\
\hline $\begin{array}{l}\text { Gini Coefficient of SMSA } \\
\text { Household Incomes }\end{array}$ & $\begin{array}{l}-5764 \\
(4894)\end{array}$ & $\begin{array}{r}-1.24 \\
(.51)\end{array}$ & $\begin{array}{c}7.3 \\
(42.5)\end{array}$ \\
\hline $\begin{array}{c}\text { U.S. Census Region Indicator } \\
\text { Variables }\end{array}$ & yes & yes & yes \\
\hline
\end{tabular}

Note: Standard errors in parentheses, except as noted. 264 observations (SMSAs).

Covariates not shown in table: share of SMSA households with $\$ 10,000-20,000$ income, share of SMSA households with $\$ 20,000-30,000$ income, ..., share of SMSA households with $\$ 50,000$ or more income, share of SMSA households who receive transfer payments, share of SMSA population who are African-American, share of SMSA population who are Hispanic, share of SMSA population who are Asian, share of SMSA population who are Native American, share of SMSA adult population who have at least 12 years of education, Herfindahl index of SMSA racial homogeneity, shares of SMSA population who are Catholic, Lutheran, Baptist, Episcopalian, Friends, Jewish, Methodist, and Presbyterian adherents. 


\section{Appendix Table 1 \\ Descriptive Statistics - Selected Variables}

SMSA-level Variable

Herfindahl Index of Public School District Enrollment Concentration

Herfindahl Index of Local Government (population) Concentration

SMSA Land Area (Hundreds of Square Miles)

Total SMSA Population (Millions)

Share of SMSA Population Urban

SMSA Per Capita Income (Thousands of $\$ 1982$, population aged $16+$ )

Share of SMSA Households with Income below Poverty Level

Share of SMSA Households Headed by Females

Share of SMSA Adult Population with $16+$ Years of Education

Per-Pupil Spending in the Pupil Schools (\$1982)

Average Teacher Salary (\$1982)

Student-Teacher Ratio

Per-Person Spending on Parks and Recreation (\$1982)

Per-Person Spending on Fire Protection (\$1982)

Per-Person Spending on Police Protection (\$1982)

Share of SMSA Enrollment in Private Schools

Individual-Level Variable

Highest Grade Completed by Age 24

High School Diploma by Age 19

Any Post-Secondary School by Age 24

Two Years of College (at a 2- or 4-year college) by Age 24

Graduated from a 4-year College by Age 24

Ln(Hourly Wage) at Most Recent Job

AFQT Percentile Score (1989 standard)

AFQT Score in Lowest 10th Percentile

AFQT Score in Lowest 25th Percentile

AFQT Score in Highest 25th Percentile

AFQT Score in Highest 10th Percentile

Parents' Highest Grade Completed (max. of mother's and father's)

African-American

Hispanic

Female

Number of Siblings
Mean Standard Deviation

\begin{tabular}{|c|c|}
\hline .31 & .25 \\
\hline .34 & .26 \\
\hline 19.54 & 22.25 \\
\hline \multirow[t]{2}{*}{.61} & 1.04 \\
\hline & .77 \\
\hline 10.30 & 1.65 \\
\hline .11 & .04 \\
\hline .10 & .02 \\
\hline .16 & .05 \\
\hline 2139.02 & 437.79 \\
\hline 17261.34 & 3121.10 \\
\hline 16.83 & 3.99 \\
\hline 25.84 & 19.62 \\
\hline 30.57 & 12.70 \\
\hline 54.62 & 20.92 \\
\hline .10 & .07 \\
\hline
\end{tabular}

Mean Standard Deviation

12.36

.70

2.17

.45

.33

.47

.24

.13

.33

2.12

.47

41.03

28.58

.37

.48

.37

.24

3.24

11.68

.43

.34

.50

.49

2.53 
Appendix Table 2

SMSA Characteristics by Rivers Quartile

\begin{tabular}{|c|c|c|c|c|}
\hline \multirow{2}{*}{ SMSA Characteristic } & \multicolumn{4}{|c|}{ Total Number of Rivers (Intra- and Inter-County): } \\
\hline & 0-2 Rivers & 3-4 Rivers & 5-7 Rivers & 8+ Rivers \\
\hline $\begin{array}{c}\text { Land Area } \\
\text { (Hundreds of Sq Miles) }\end{array}$ & $\begin{array}{l}18.6 \\
(29.9)\end{array}$ & $\begin{array}{l}16.7 \\
(17.4)\end{array}$ & $\begin{array}{c}18.9 \\
(14.2)\end{array}$ & $\begin{array}{c}24.2 \\
(16.4)\end{array}$ \\
\hline $\begin{array}{c}\text { Population } \\
\text { (Millions) }\end{array}$ & $\begin{array}{c}.36 \\
(.40) \\
-\ldots \ldots\end{array}$ & $\begin{array}{c}.58 \\
(1.21) \\
(1.2)\end{array}$ & $\begin{array}{r}.59 \\
(.97) \\
. . . . .\end{array}$ & $\begin{array}{l}1.09 \\
(1.5)\end{array}$ \\
\hline Share of Population Urban & $\begin{array}{c}.79 \\
(.12) \\
\cdots \cdots \cdots \cdots . . .\end{array}$ & $\begin{array}{l}.79 \\
(.12)\end{array}$ & $\begin{array}{c}.78 \\
(.13) \\
\ldots \ldots\end{array}$ & $\begin{array}{c}.77 \\
(.13)\end{array}$ \\
\hline $\begin{array}{c}\text { Per Capita Income, age 16+ } \\
\text { (thousands 1982\$) }\end{array}$ & $\begin{array}{l}10.2 \\
(1.9)\end{array}$ & $\begin{array}{l}10.3 \\
(1.4)\end{array}$ & $\begin{array}{l}10.2 \\
(1.3)\end{array}$ & $\begin{array}{l}10.6 \\
(1.6)\end{array}$ \\
\hline $\begin{array}{l}\text { Share of Households with } \\
\text { Income below Poverty Level }\end{array}$ & $\begin{array}{l}.13 \\
(.05)\end{array}$ & $\begin{array}{l}.11 \\
(.03)\end{array}$ & $\begin{array}{c}.12 \\
(.03)\end{array}$ & $\begin{array}{l}.11 \\
(.03)\end{array}$ \\
\hline $\begin{array}{l}\text { Share of Households Headed } \\
\text { by Females }\end{array}$ & $\begin{array}{l}.10 \\
(.02)\end{array}$ & $\begin{array}{l}.10 \\
(.02)\end{array}$ & $\begin{array}{l}.10 \\
(.02) \\
. . \ldots \ldots\end{array}$ & $\begin{array}{l}.10 \\
(.02)\end{array}$ \\
\hline $\begin{array}{l}\text { Share of Population African- } \\
\text { American }\end{array}$ & $\begin{array}{l}.11 \\
(.10)\end{array}$ & $\begin{array}{c}.11 \\
(.08) \\
\ldots \ldots \ldots\end{array}$ & $\begin{array}{l}.12 \\
(.10)\end{array}$ & $\begin{array}{l}.08 \\
(.08)\end{array}$ \\
\hline Share of Population Hispanic & $\begin{array}{c}.09 \\
(.16)\end{array}$ & 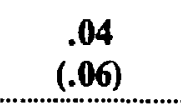 & $\begin{array}{l}.05 \\
(.09)\end{array}$ & $\begin{array}{l}.04 \\
(.04)\end{array}$ \\
\hline $\begin{array}{l}\text { Share of Adult Population } \\
\text { with Education 12+ Years }\end{array}$ & $\begin{array}{c}.67 \\
(.09)\end{array}$ & $\begin{array}{c}.68 \\
(.07) \\
\ldots \ldots . . .\end{array}$ & $\begin{array}{l}.67 \\
(.06)\end{array}$ & $\begin{array}{l}.70 \\
(.07)\end{array}$ \\
\hline $\begin{array}{l}\text { Share of Adult Population } \\
\text { with Education } 16+\text { Years }\end{array}$ & $\begin{array}{l}.16 \\
(.05)\end{array}$ & $\begin{array}{l}.16 \\
(.06)\end{array}$ & $\begin{array}{l}.15 \\
(.04)\end{array}$ & $\begin{array}{l}.17 \\
(.05)\end{array}$ \\
\hline
\end{tabular}


Appendix Table 3

State Summaries: Market Concentration in Schooling, Land Area of Public School Districts, and Share of Public School Spending from State Funds

For SMSAs in this State:

Public School District Herfindahl Index

$\begin{array}{lr}\text { Alabama } & .38 \\ \text { Alaska } & 1.00 \\ \text { Arizona } & .19 \\ \text { Arkansas } & .16 \\ \text { California } & .10 \\ \text { Colorado } & .25 \\ \text { Connecticut } & .05 \\ \text { Delaware } & .25 \\ \text { Florida } & .61 \\ \text { Georgia } & .35 \\ \text { Hawaii } & 1.00 \\ \text { Idaho } & .55 \\ \text { Illinois } & .13 \\ \text { Indiana } & .27 \\ \text { Iowa } & .40 \\ \text { Kansas } & .35 \\ \text { Kentucky } & .30 \\ \text { Louisiana } & .57 \\ \text { Maine } & .23 \\ \text { Maryland } & .05 \\ \text { Massachusetts } & .05 \\ \text { Michigan } & .11 \\ \text { Minnesota } & .11 \\ \text { Mississippi } & .22 \\ \text { Missouri } & .25 \\ \text { Montana } & .71 \\ \text { Nebraska } & .40 \\ \text { Nevada } & 1.00 \\ \text { New Hampshire } & .16 \\ \text { New Jersey } & .10 \\ \text { New Mexico } & .90 \\ \text { New York } & .21 \\ \text { North Carolina } & .45 \\ \text { North Dakota } & .28 \\ \text { Ohio } & .12 \\ \text { Oklahoma } & .24 \\ \text { Oregon } & .16 \\ \text { Pennsylvania } & .29 \\ \text { Rhode Island } & .08 \\ \text { South Carolina } & .34 \\ \text { South Dakota } & .49 \\ \text { Tennessee } & .27 \\ \text { Texas } & .29 \\ \text { Utah } & .14 \\ \text { Vermont } & \\ \end{array}$

Number of School Districts Per Hundred Sq Miles

1.5

.4

1.1

1.5

8.0

2.2

11.0

2.0

2.7

2.2

15.4

1.2

11.1

3.7

3.5

1.6

5.3

4.0

4.0

7.8

13.7

6.1

4.1

1.9

3.3

.7

4.7

.1

6.7

40.6

.7

31.4

2.4

.8

5.9

2.0

3.0

10.0

14.0

1.5

1.1

1.8

2.1

.2

3.7
Share of Public School Spending from State

.68

.91

.56

.60

.57

.46

.32

.81

.59

.54

1.00

.58

.41

.59

.54

.50

.62

.66

.45

.22

.41

.28

.67

.59

.46

.49

.42

.69

.09

.39

.82

.51

.70

.65

.46

.65

.38

.48

.39

.54

.35

.49

.53

.62

.30 
Virginia

Washington

West Virginia

Wisconsin
.29

.17

.50

.22
2.6

2.0

1.4

10.3
.49

.78

.63

.44 
Appendix Table 4

Market Concentration in Elementary and Secondary Schooling by SMSA

SMSA

Abilene TX

Akron $\mathrm{OH}$

Albany GA

Albany-Schenectady-Troy NY

Albuquerque NM

Alexandria LA

Allentown-Bethlehem-Easton PA NJ

Altoona PA

Amarillo TX

Anaheim-Santa Ana-Garden Grove CA

Anchorage AK

Anderson IN

Ann Arbor MI

Anniston AL

Appleton-Oskkosh WI

Asheville NC

Atlanta GA

Atlantic City NJ

Augusta GA SC

Austin TX

Bakersfield CA

Baton Rouge LA

Battle Creek MI

Bay City MI

Beaumont-Port Arthur-Orange TX

Billings MT

Biloxi-Guifport MS

Binghamton NY PA

Birmingham PA

Bloomington IN

Bloomington-Normal IL

Boise City ID

Boston-Lowell-Brockton

-Lawrence-Haverhill MA NH $\quad .01$

Bradenton FL

Bridgeport-Stamford-Norwalk-Danbury CT

New Bedford-Fall River MA

Brownsville-Harlingen-San Benito TX

Bryan-College Station TX

Buffalo NY

Burlington NC

Canton $\mathrm{OH}$

Cedar Rapids IO

Champaign-Urbana-Rantoul IL

Charleston-North Charleston SC

Charleston WV

Charlotte-Gastonia NC

Chattanooga TN GA

Chicago IL

Cincinnati OH KY IN
Herfindahl Index of Public

School Enrollment Conc.

$$
.49
$$

.13

.81

.03

.90

.78

.05

.31

.54

.04

1.0

.38

.17

.34

.11

.78

.13

.09

.40

.44

.10

.54

.10

.37

.10

.63

.15

.06

.23

.71

.21

.55

.70

.07

.08

.26

1.0

.06

1.0

.08

.32

.16

.44

.74

.48

.23

.12

.16
Share of Enrollment in Private Schools

.01

.08

.06

.13

.08

.10

.10

.11

.04

.06

.05

.04

.07

.04

.16

.07

.06

.15

.09

.05

.03

.12

.02

.16

.03

.05

.09

.05

.06

.02

.10

.05

.10

.06

.13

.09

.05

.18

.14

.05

.07

.08

.03

.10

.04

.06

.10

.15

.14 
Clarksville-Hopkinsville TN KY

Cleveland $\mathrm{OH}$

Colorado Springs CO

Columbia MO

Columbia SC

Columbus GA AL

Columbus $\mathrm{OH}$

Corpus Christi TX

Dallas-Fort Worth TX

Davenport-Rock Island-Moline IO IL

Dayton OH

Daytona Beach FL

Decatur IL

Denver-Boulder CO

Des Moines IO

Detriot MI

Dubuque IO

Duluth-Superior MN WI

Eau Claire WI

El Paso TX

Elmira NY

Erie PA

Eugene-Springfield OR

Evansville IN KY

Fargo-Moorhead ND MN

Fayetteville NC

Fayetteville-Springdale AZ

Flint MI

Florence AL

Fort Collins CO

Fort Lauderdale-Hollywood FL

Fort Myers FL

Fort Smith AR OK

Fort Wayne IN

Fresno CA

Gadsden AL

Gainesville FL

Galveston-Texas City TX

Gary-Hammond-East Chicago IN

Grand Forks ND MN

Grand Rapids MI

Great Falls MT

Greeley CO

Green Bay WI

Greensboro-Winston Salem-High Point NC

Greenville-Spartanburg SC

Hamilton-Middletown $\mathrm{OH}$

Harrisburg PA

Hartford CT

Honolulu HA

Houston TX

Huntington-Ashland WV KY OH

Huntsville AL

Indianapolis IN

Jackson MI 
Jackson MS

Jacksonville FL

Jersey City NJ

.24

Johnson City-Kingsport-Bristol TN VA

.01

Johnstown PA

Kalamazoo-Portage MI

.11

Kankakee IL

Kansas City MO KS

Kenosha WI

Killeen-Temple TX

Knoxville TN

Kokomo IN

La Crosse WI

Lafayette LA

Lafayette-West Lafayette IN

Lake Charles LA

Lakeland-Winter Haven FL

Lansing-East Lansing MI

Laredo TX

Las Vegas NV

.10

Lawrence KS

Lawton OK

Lewiston-Auburn ME

1.0

Lexington-Fayette KY

Lima $\mathrm{OH}$

Lincoln NE

Little Rock-North Little Rock AR

Long Branch-Asbury Park NJ

Longview TX

Lorain-Elyria $\mathrm{OH}$

Los Angeles-Long Beach CA

Louisville KY IN

Lubbock TX

Lynchburg VA

Macon GA

Madison WI

Manchester-Nashua NH

Mansfield $\mathrm{OH}$

McAllen-Pharr-Edinburg TX

Melbourne-Titusville-Cocoa FL

Memphis TN AR MS

Miami FL

Midland TX

Milwaukee WI

Minneapolis-St. Paul MN WI

Mobile AL

Modesto CA

Monroe LA

Montgomery AL

Muncie IN

Muskegon-Norton Shores-Muskegon Hts MI

Nashville-Davidson TN 
New Haven-Waterbury-Meriden CT

New London-Norwich CT $\quad .08$

New Orleans LA $\quad .36$

.26

New York NY NJ $\quad .53$

.20

Newark NJ

.15

Newport News-Hampton VA

.01

.31

.06

Norfolk-Virginia Beach-Portsmouth VA NC $\quad .24 \quad .07$

Northeast Pennsylvania PA $\quad .05 \quad .15$

Odessa TX

$.76 \quad .03$

Oklahoma City OK $\quad .13 \quad .04$

Omaha NE IO $\quad .23$

.13

Orlando FL

.44

Owensboro KY

.51

Oxnard-Simi Valley-Ventura CA

$.11 \quad .06$

Panama FL

$.79 \quad .06$

Parkersburg-Marietta WV OH $\quad .35 \quad .03$

Pascagoula-Moss Point MS $\quad .26 \quad .05$

Paterson-Clifton-Passaic NJ $\quad .15 \quad .15$

Pensacola FL $\quad .53 \quad 10$

Peoria IL $\quad .10 \quad .06$

Petersburg-Colonial Hts-Hopewell VA $\quad .21 \quad .04$

Philadelphia PA NJ $\quad .10 \quad .21$

$\begin{array}{lll}\text { Phoenix AZ } & .05 & .06\end{array}$

Pine Bluff AR $\quad .25 \quad .06$

Pittsburgh PA $\quad .03 \quad 11$

$\begin{array}{lll}\text { Pittsfield MA } & .18 & .10\end{array}$

Portland ME $\quad .33 \quad 02$

Portland OR WA $\quad .07 \quad .05$

Poughkeepsie NY $\quad .13 \quad .08$

Providence-Warwick-Pawtucket RI $\quad .05 \quad .14$

Provo-Orem UT $\quad .38 \quad .00$

$\begin{array}{lll}\text { Pueblo CO } & .76 & .00\end{array}$

$\begin{array}{lll}\text { Racine WI } & .59 & .17\end{array}$

Raleigh-Durham NC $\quad .54 \quad 10$

Reading PA $\quad .43 \quad .04$

Reno NV $\quad 1.0 \quad 05$

Richland-Kennewick WA $\quad .24 \quad .05$

Richmond VA $\quad .24 \quad 06$

Riverside-San Bernardino-Ontario CA $\quad .03 \quad .06$

$\begin{array}{lll}\text { Roanoke VA } & .42 & .03\end{array}$

$\begin{array}{lll}\text { Rochester MN } & .58 & .09\end{array}$

Rochester NY $\quad .05 \quad .11$

Rockford IL $\quad .34 \quad 10$

$\begin{array}{lll}\text { Sacramento CA } & .10 & .07\end{array}$

$\begin{array}{lll}\text { Saginaw MI } & .15 & .09\end{array}$

St. Cloud MN $\quad .16 \quad .10$

$\begin{array}{lll}\text { St. Joseph MO } & .57 & .07\end{array}$

St. Louis MO IL $\quad .04 \quad 16$

Salem OR $\quad .30 \quad .06$

Salinas-Seaside-Monteray CA $\quad .11 \quad .04$

Salt Lake City-Odgen UT $\quad .18 \quad 01$

San Angelo TX $\quad .82 \quad .00$

San Antonio TX $\quad .12 \quad .06$

San Diego CA $\quad .11 \quad .06$

San Francisco-Oakland CA $\quad .03 \quad .10$ 
Santa Barbara-Santa Maria-Lompoc CA

Santa Cruz CA

Santa Rosa CA

Sarasota FL

Savannah GA

Seattle-Everett WA

Sherman-Denison TX

Shreveport LA

Sioux City IO NE

Sioux Falls SD

South Bend IN

Spokane WA

.10

Springfield IL

.16

Springfield-Chicopee-Holyoke MA

Springfield MO

Springfield $\mathrm{OH}$

Steubenville-Wierton OH WV

Stockton CA

Syracuse NY

Tacoma WA

Tallahassee FL

.16

.16

.10

.20

.06

.06

.08

.18

.05

Tampa-St. Petersburg FL

.12

Terre Haute IN

.10

Texarkana TX AR

.03

Toledo OH MI

.00

Topeka KS

.13

Trenton NJ

.05

Tucson AZ

.20

.05

Tulsa OK

.03

Tuscaloosa AL

.06

Tyler TX

.02

Utica-Rome NY

.09

Vallejo-Fairfield-Napa CA

Vineland-Millville-Bridgeton NJ

.06

Waco TX

.08

Washington DC MD VA

.05

Waterloo-Cedar Falls IO

.18

.13

West Palm Beach-Boca Raton FL

.18

Wheeling WV OH

Wichita KS

Wichita Falls TX

New London-Norwich CT

Williamsport PA

Wilmington DE NJ MD

Worcester-Fitchburg-Leominster MA

Yakima WA

York PA

.13

.08

.04

.04

.23

.03

.08

.03

Youngstown-Warren $\mathrm{OH}$ 
Appendix Table 5

Variation in Student Performance and Market Concentration in Public Schooling

\begin{tabular}{||cccc||}
\hline & \multicolumn{3}{c}{ Dependent Variable is SMSA Inter-Quartile Range for } \\
& $\begin{array}{c}\text { Highest Grade } \\
\text { Completed by age 24 }\end{array}$ & $\begin{array}{c}\text { Ln(Hourly Wage) } \\
\text { on Most Recent Job }\end{array}$ & AFQT Percentile Score \\
\hline SMSA Herfindahl Index of & 1.39 & -.06 & 22.16 \\
Public School Enrollment Conc & $(2.11)$ & $(.48)$ & $(22.78)$ \\
Share of Public School Spending & .38 & -.27 & 16.17 \\
from State Funds & $(1.33)$ & $(.35)$ & $(14.48)$ \\
SMSA Land Area & -.02 & $1.6 \mathrm{e}-3$ & -.15 \\
(Hundreds of Square Miles) & $(.01)$ & $(4.1 \mathrm{e}-4)$ & $(.09)$ \\
SMSA Land Area Squared & $-8.9 \mathrm{e}-7$ & $3.3 \mathrm{e}-8$ & $5.1 \mathrm{e}-6$ \\
(Hundreds of Square Miles) & $(6.1 \mathrm{e}-7)$ & $(1.4 \mathrm{e}-7)$ & $(6.6 \mathrm{e}-6)$ \\
Total SMSA Population & -.10 & .03 & .74 \\
(Millions) & $(.14)$ & $(.03)$ & $(1.57)$ \\
Share of SMSA Population & -.22 & -.13 & -.40 \\
Urban & $(1.79)$ & $(.44)$ & $(19.89)$ \\
SMSA Per Capita Income & .06 & .04 & 5.11 \\
(Thousands) & $(.22)$ & $(.05)$ & $(2.48)$ \\
Share of SMSA Households with & .83 & 1.21 & -12.58 \\
Income below Poverty Level & $(13.47)$ & $(3.28)$ & $(147.50)$ \\
Share of SMSA Households & 19.15 & 5.12 & 350.31 \\
Headed by Females & $(16.41)$ & $(3.88)$ & $(179.81)$ \\
Share of SMSA Adult Population & 7.33 & 1.28 & -12.67 \\
with 16 + Years of Education & $(5.74)$ & $(1.43)$ & $(62.55)$ \\
Gini Coefficient on SMSA & 6.30 & -2.19 & 56.12 \\
Household Incomes & $(26.41)$ & $(6.83)$ & yes \\
U.S. Census Region Indicator & yes & yes & \\
Variables & & & \\
\hline \hline & & & \\
\hline
\end{tabular}

Note: Standard errors in parentheses, except as noted. 264 observations (SMSAs).

Covariates not shown in table: share of SMSA households with $\$ 10,000-20,000$ income, share of SMSA households with $\$ 20,000-30,000$ income, share of SMSA households with $\$ 30,000-40,000$ income, share of SMSA households with $\$ 50,000$ or more income, share of SMSA households who receive transfer payments, share of SMSA population who are African-American, share of SMSA population who are Hispanic, share of SMSA population who are Asian, share of SMSA population who are Native American, share of SMSA adult population who have at least 12 years of education, Herfindahl index of SMSA racial homogeneity, shares of SMSA population who are Catholic, Lutheran, Baptist, Episcopalian, Friends, Jewish, Methodist, and Presbyterian adherents. 